EISSN: $2706-7947 \quad$ ISSN: 2077- 4613

DOI: 10.36632/mejas/2021.11.2.40

Journal homepage: www.curresweb.com

Pages: 481-502

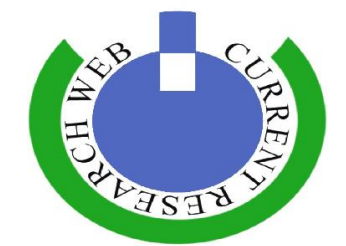

\title{
ASTER Data and mineral studies for mapping the alteration zones at Wadi Sibrit- Wadi Urf Abu Hamam area, South Eastern Desert, Egypt
}

\section{Nehal M.A. Soliman', Hatem M. El-Desoky², Mohamed El Rahmany M. Mohamed ${ }^{3}$, Hamed Maira ${ }^{3}$ and Wael Fahmy ${ }^{2}$}

${ }^{I}$ National Authority of Remote Sensing and Space Science, Egypt.

${ }^{2}$ Geological Department. Faculty of Science, Azhar University, Egypt.

${ }^{3}$ Nuclear Materials Authority, Egypt.

Received: 20 April $2021 \quad$ Accepted: 19 May Published: 30 May 2021

\begin{abstract}
This study aims at mapping the alteration zones and the altered minerals in the exposed rocks of Wadi Sibrit-Wadi Urf Abu Hamam area. The processed ASTER images in varied approaches, supported by field geology as well as mineralogical studies help in differentiating the types of alteration zones from their host rocks. Chloritization, kaolinitization, and sericitization and epidotization are the main types of alterations detected, associating with the related altered minerals eg; chlorite, kaolinite, sericite, illite, alunite, epidote, quartz, and montmorillonite. The high lineament density areas are marked by the extensively alterations due to the mineral bearing hydrothermal solutions activities along the abundant fractures, suggesting a suitable environment for mineral exploration in such areas. The mineral investigation of the selected samples from the alteration zones reveals presence of sulphide minerals such as pyrite, chalcopyrite, galena; and iron oxides as magnetite, ilmenite, and goethite forming valid host minerals for gold exploration in these alteration zones. Some accessory minerals of albite, calcite, lepidolite, rutile, barite, zircon, thorite, monazite, and brookite were found. The study area is built of metavolcanics intruded by metagabbros, Quartz diorite and tonalite rocks. The Dokhan volcanics, hornblende granites, quartz monzogranites and alkali feldspar granites are exposed in separate and linked masses. Various dykes of different compositions of bostonite, trachyte, dacite, and quartz veins are crosscutting the country rocks in the study area. Meanwhile, dismembers of Phanerozoic rocks represented by lower Nubia sandstones, Natash volcanic and Upper Nubia sandstones.
\end{abstract}

Keywords: Remote sensing, ASTER image, Wadi Sibrit-Urf Abu Hamam, Hydrothermal alteration zones, Ore mineralogy.

\section{Introduction}

Wadi Sibrit and Wadi Urf Abu Hama area lies in the South Eastern Desert (SED) of Egypt, forming a part of the Arabian-Nubian Shield (ANS). It is located between Latitudes $24^{\circ} 40^{\prime}-24^{\circ} 47^{\prime} \mathrm{N}$ and Longitudes $33^{\circ} 52^{\prime}-34^{\circ} 05^{\prime} \mathrm{E}$, covering an area of about $700 \mathrm{~km}^{2}$ (Fig.1). The study district is totally covered by the Neoproterozoic basement rocks of the Pan-African terrain and the Phanerozoic rocks, exposed as rugged peaks of moderate to high topography.

ANS is a tectonized regime involving complicated geologic processes producing mineralizing fluids that were sources for ore deposition when expelled and passed from the deeper parts through the rock fissures and fractures to the earth surfaces (Oliver, 1986; Nesbitt, 1984; Garven et al., 1999). Hydrothermal activity derived either by metamorphism or cooling effects of early Cambrian subduction-related calc-alkalic magmatism that generated various mineral occurrences (El Gaby et al., 1988; Johnson et al., 2011). The hydrothermal solutions activity led to the formation of hydrothermal alterations along the fractured zones among which they passed. The ore deposits are often produced by fluid flow processes that alter the mineralogy and chemistry of the country rock. The alteration zones 
have spectral characteristics and reflectances differ from the host rocks due to the mineral alteration products which can be assigned by the Remote sensing techniques.

Remote sensing approaches can provide detailed information on the mineralogy weathering characteristics and mineral exploration, particularly for remote areas with little or no access, or areas that lack detailed topographic or geologic base maps (Rowan et al., 2003). ASTER sensor can achieve a higher degree of accuracy in the spectral identification of rocks and minerals (Crosta and Filho, 2003). ASTER shortwave infrared (SWIR) bands are excellent for mapping clastic and carbonate stratigraphy in volcanic environments and have also been shown to be effective in predicting the occurrence of certain mineral groups and specific minerals (kaolinite, alunite, illite, muscovite, montmorillonite, chlorite, calcite, dolomite, serpentine, and others). Appropriate results of extracting and mapping the lithologic information and alteration zones with characteristic minerals can be processed through ASTER data, e.g.; (Ninomiya, 2003; Zhang et al., 2007, Ramadan and Abdel Fattah 2010; Pour and Hashim 2011a, 2012b, Bedini 2011; Van Ruitenbeek 2 et al., 2012; Amer et al., 2012; Rajendran et al., 2011, 2012; Salem, et al., 2015, 2016; Gemail, et al., 2016; Elhebiry, et al., 2019; Abu ElLeil, et al., 2019; El Ghrabawy, et al., 2019; Zoheir, et al., 2019).

The aim of the study is to differentiate and map the alteration zones and their characterized altered minerals in the distinct geological and structural environments at Wadi Sibrit- Wadi Urf Abu Hamam district. The spectral identification of potential areas of hydrothermal alteration for mineral exploration is a common application of remote sensing, especially ASTER data, which might be verified by field work and supported by analytical techniques.

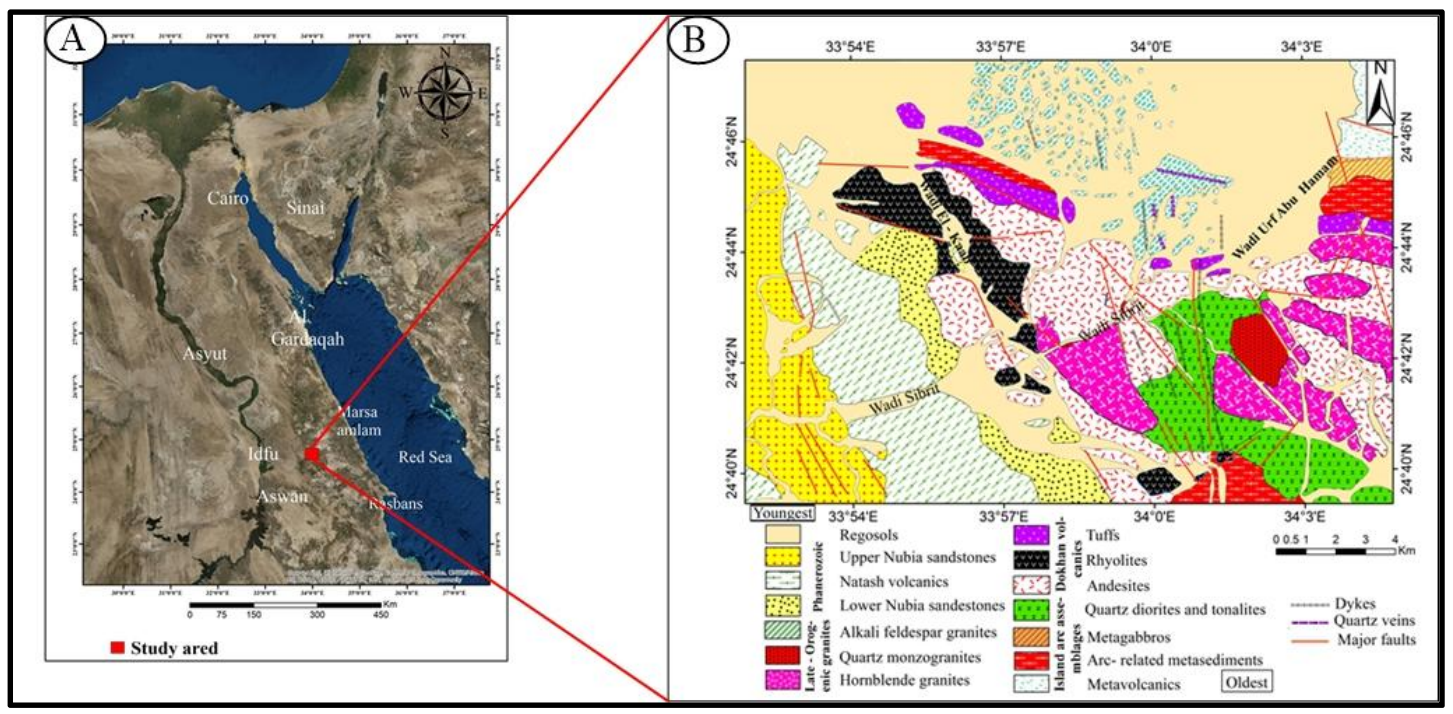

Fig. 1: Simplified sketch maps (A) Location map of the Wadi Sibrit - Wadi Urf Abu Hamam district (B) Geological map of Wadi Sibrit - Urf Abu Hamam district (Modified after Sabet et al., 1973).

\section{Materials and Methods}

ASTER data and geological field observations supported by spectral reflectance measurements, microscopic examinations, and powder XRD analyses conclude the results of this study. A single ASTER Level 1B was used for this study. Therefore, several pre-processing techniques were applied to subset data covering the study area to be suitable for further image processing techniques. The spectral reflectance measurements of the samples were made in the laboratory using an Analytical Spectral Devices (ASD). Field Spectroradiometer are spanning between the 0.4 to $2.5 \mu \mathrm{m}$ regions of the spectrum. A simplified geologic map of the study area was derived from the data.

\subsection{Remote sensing}

A single ASTER data (free level IB ASTER VNIR \& SWIR data Granule ID: ASTL1B 0403150819140808041013) with a minimal cloud cover - acquired on October 7, 2007 - were digitally pre-processed for geo-referencing, atmospheric, and radiometric cross-talk correction of ASTER-SWIR bands, layer stacking of VNIR-SWIR bands in unique nine bands data-cube, and ortho-rectification of 
data using SRTM topographic data. These are performed by ENVI 5.3 and ArcGIS ver. 10.3 through the conversion of the data to real-world coordinates on the area maps to improve the quality of the raw data.

The lineaments which reflect the passages of the mineral bearing hydrothermal solution were extracted automatically from the principal component image (PC1) as favorable areas valid for mineral explorations. For alteration zone mapping, Constrained Energy Minimization (CEM) and Crosta PC techniques have been used as follows; the used remote sensing methodology is presented in the given flowchart (Fig. 2).

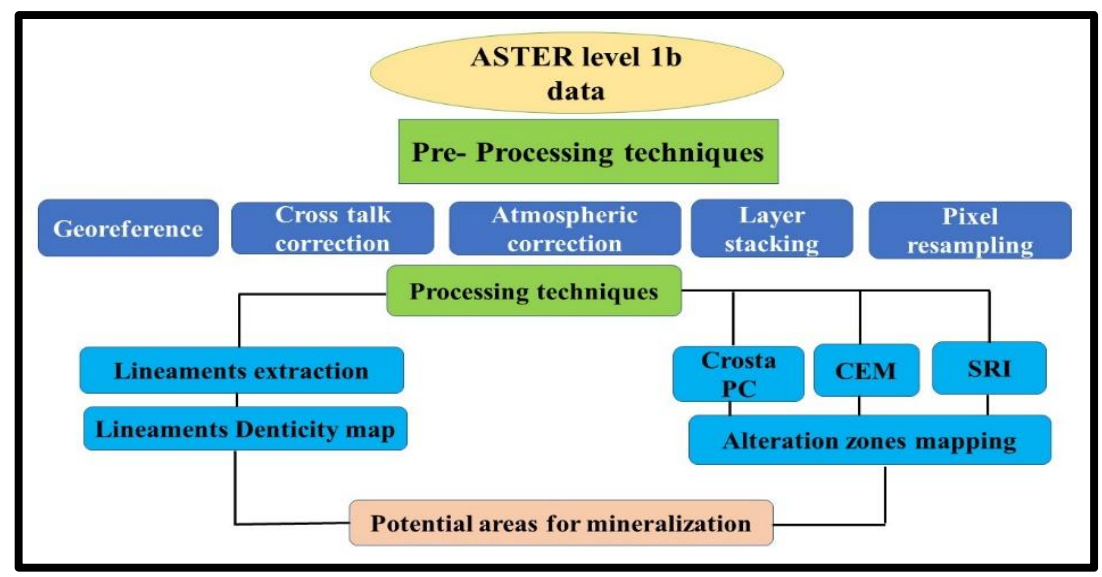

Fig. 2: Remote sensing methodology flow chart.

\subsubsection{Crosta principal Component (Crosta PC)}

Crosta Technique utilizes absorption features and variations in the shape of the spectral curve to identify target materials. The technique originally called Oriented Principal Component Selection. (Crosta and Moore, 1989) using only bands that would theoretically describe a feature under study and avoiding band that would cause interference. Crosta and Moore, (1989); studied the spectra of the alteration minerals from the United States Geological Survey (USGS) spectral library.

This technique was used for mineral exploration in bands of Landsat TM data (Crosta and Moore, 1989; Loughlin, 1991; Ruiz-Armenta and Prol-Ledesma, 1998; Tangestani and Moore 2002; Carranza and Hale, 2002) and on ASTER data (Crosta, 2003).

\subsubsection{Constrained Energy Minimization (CEM) technique}

CEM performs a matched filter (MF) of hyperspectral/multispectral images, and then linearly constrains a desired target signature while minimizing other unknown signatures where the only required knowledge is the training target spectra to be provided as user end members. Moreover, it has the advantage of being a straightforward technique that can be used for alteration zone mapping with less field visits.

\subsubsection{Mineral spectral indices}

The Aster spectral mineralogical indices are useful in the discriminations of the lithological and hydrothermal alteration zones (Ninomiya, 2003; Ninomiya et al., 2005; Di-Tommaso and Rubinstein, 2007; Zhang et al., 2007; Khan and Mahmood, 2008; Zoheir and Emam, 2014). The VNIR and SWIR band ratios are used to identify the mineral indices by using absorption features of the different minerals in the spectral range of ASTER (Ninomiya, 2003). For example, mineral indices (Ninomiya, 2003) including $\mathrm{OH}$-bearing minerals (OHI), kaolinite (KLI), sericite (SRI), and calcite (CLI) are derived from the (VNI+SWIR) bands by calculating given equations in ENVI 5.3 as follows:

$\mathrm{OH}$-bearing altered minerals index $(\mathrm{OHI})=$ ASTER bands $(7 / 6) \times(4 / 6)$

Kaolinite index $(\mathrm{KLI})=$ ASTER bands $(4 / 5) \times(8 / 6)$

Sericite index $(\mathrm{SRI})=$ ASTER bands $(5+7 / 6)$

Calcite index $(\mathrm{CLI})=$ ASTER bands $(6 / 8) \times(9 / 8)$. 


\subsubsection{Lineament extractions}

Lineaments are extracted and analyzed based on the enhanced space-borne data, GIS, and integrated with the geometric approaches of structural geology. The ASTER satellite images are utilized in the current work to conduct detailed analysis of structural lineaments such as dykes and faults. Different convolution kernels are applied to the satellite images to extract the major and minor structural lineaments such as low-pass frequency, directional filters, and compass gradient convolutions (Koike et al., 1995; Mah et al., 1995; Novak and Soulakellis 2000; Arnous and Green 2011; Arnous 2011).

In this study, automatic lineament extraction has been carried out using the most widely used software for such purpose (the LINE module of the PCI Geomatica package using the default parameters to adjustment of the Edge gradient threshold to 40 pixels).

\subsection{Field and laboratory work}

A field trip was carried out to collect samples from different locations based on the ASTER data analysis of the study area. The mineralogical studies of minerals ores had been carried out by twenty thin polished slabs from the study district were prepared. These slabs were studied by using the polarizing and reflected light microscope; about twenty photomicrographs were taken showing the opaque ore minerals, textures, and their specific petrographic features as well as XRD and EDAX-SEM techniques.

\section{Results and Interpretations}

\subsection{Interpretations of the processed images}

\subsubsection{Crosta principal Component (Crosta PC)}

According to the alteration products found in the study area through a field, petrographic and previous works, the following common endmember alteration minerals were selected: chlorite, kaolinite, illite, alunite, epidote, iron oxides, sericite and montmorillonite. Crosta and Moore, (1989); studied the spectra of the alteration minerals from the United States Geological Survey (USGS) spectral library (Fig. 3) from the analysis of the spectral behavior of these alteration minerals he defined the best four bands for each alteration mineral; two, representing the maximum reflectance and the other two, representing the absorption features as presented in (Table.1).

The result of Crosta PC approach revealed presence of many hydrothermal alteration minerals.

\section{Chlorite}

The Eigenvector statistics for the VNIR-SWIR domains show that PC3 has high positive loading from band5 (0.990534) and band $8(0.110754)$. The result shows chloritization as green colored areas (Fig.4A).

\section{Kaolinite}

PC2 has the high opposite signed loadings for bands6 (0.112611) and band 7 (0.990902), so kaolinite will appear as bright pixels. The resultant image represents the kaolinite mineral as magenta (Fig. 4-B).

Illite

PC3 has highest opposite signed loadings for bands 7 (0.978561) and band $6(0.187734)$. The resultant image represents the illite mineral as electron green (Fig.4-C).

\section{Alunite}

PC2 has high opposite signed loadings for bands 5 (0.997618) and band 7 (0.050712), so alunite will appear as dark pixels. The resultant image represents alunite mineral as red (Fig. 4.D). 


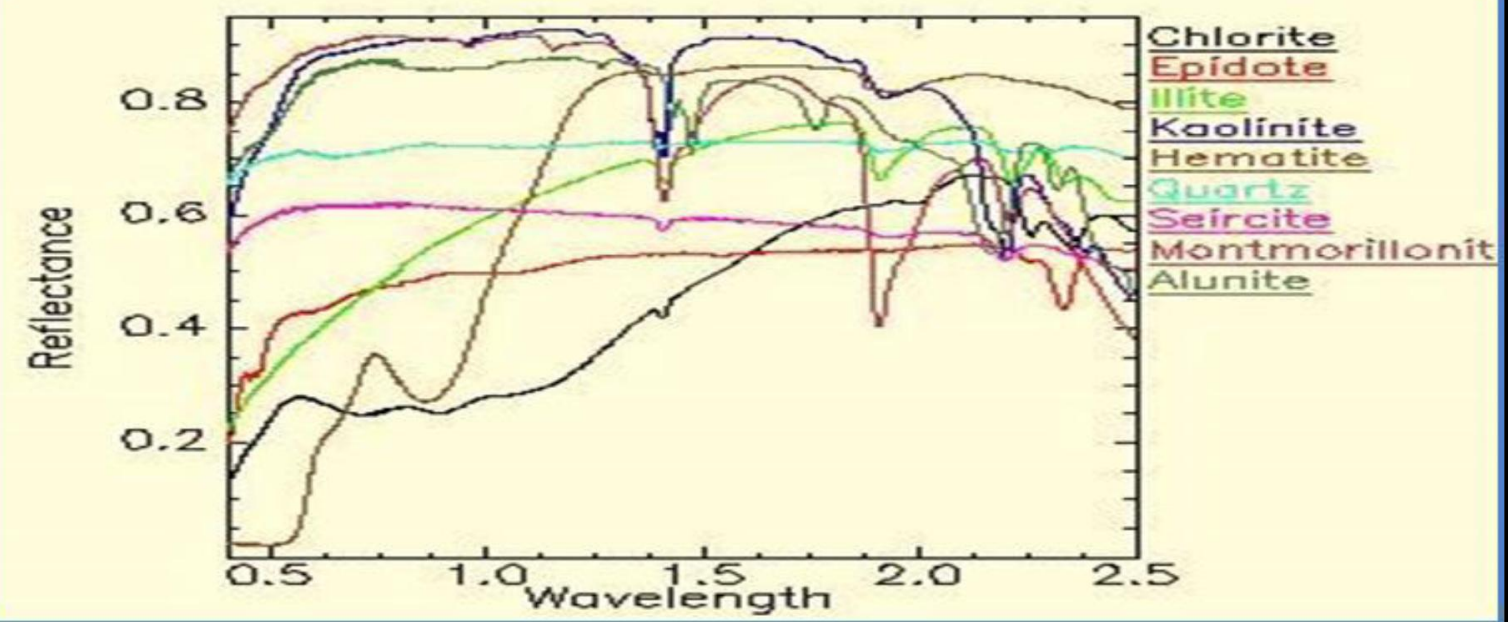

Fig. 3: The USGS library spectra of the studied minerals superimposed on ASTER data band intervals in the VNIR-SWIR region.

Table. 1: Input bands for FPCS (Crosta) Analysis of the selected minerals.

\begin{tabular}{|c|c|c|c|c|c|}
\hline \multirow{2}{*}{ Minerals } & \multicolumn{2}{|c|}{ VNIR-SWIR (Reflectance) } & \multirow{2}{*}{ Minerals } & \multicolumn{2}{|c|}{ VNIR-SWIR (Reflectance) } \\
\hline & High & Low & & High & Low \\
\hline \multirow{2}{*}{ Chlorite } & Band 1 & Band 2 & \multirow{2}{*}{ Hematite } & Band 2 & Band 3 \\
\hline & Band 5 & Band 8 & & Band 4 & Band 9 \\
\hline \multirow[b]{2}{*}{ Kaolinite } & Band 4 & Band 6 & \multirow[b]{2}{*}{ Montmorillonite } & Band 3 & Band 6 \\
\hline & Band 7 & Band 9 & & Band 7 & Band 9 \\
\hline \multirow{2}{*}{ Illite } & Band 4 & Band 6 & \multirow{2}{*}{ Sericite } & Band 4 & Band 6 \\
\hline & Band 7 & Band 8 & & Band 7 & Band 8 \\
\hline \multirow{2}{*}{ Epidote } & Band 5 & Band 3 & \multirow{2}{*}{ Alunite } & Band 3 & Band 5 \\
\hline & Band 6 & Band 8 & & Band 7 & Band 9 \\
\hline
\end{tabular}

\section{Epidote}

PC3 has the highest opposite signed loadings for bands 5 (-0.013934) and band 3 (0.043601), the resultant image represents epidote mineral as gold (Fig.4-E).

\section{Sericite}

PC3 has high opposite signed loadings for bands 7 (0.978561) and band $6(0.187734)$, so sericite will appear as dark pixels, the resultant image represents sericite mineral as blue color (Fig. 4-F).

\section{Montmorillonite}

PC2 has high positive loading from band 7 (0.042628) and band 6 (0.998041), the resultant image represents montmorillonite mineral as gold (Fig. 4-G).

\section{Hematite}

Hematite has a remarkable high reflectance in bands 2 and 4 besides low reflectance in bands 3 and 9 in the VNIR-SWIR spectral region; these bands were used as input bands in the PCA process producing four PCs with their eigenvector statistics in (Table. 2). PC3 has high positive loading from band $3(0.075309)$ and band $4(0.995614)$, the resultant image represents hematite mineral as yellow (Fig.4H). 


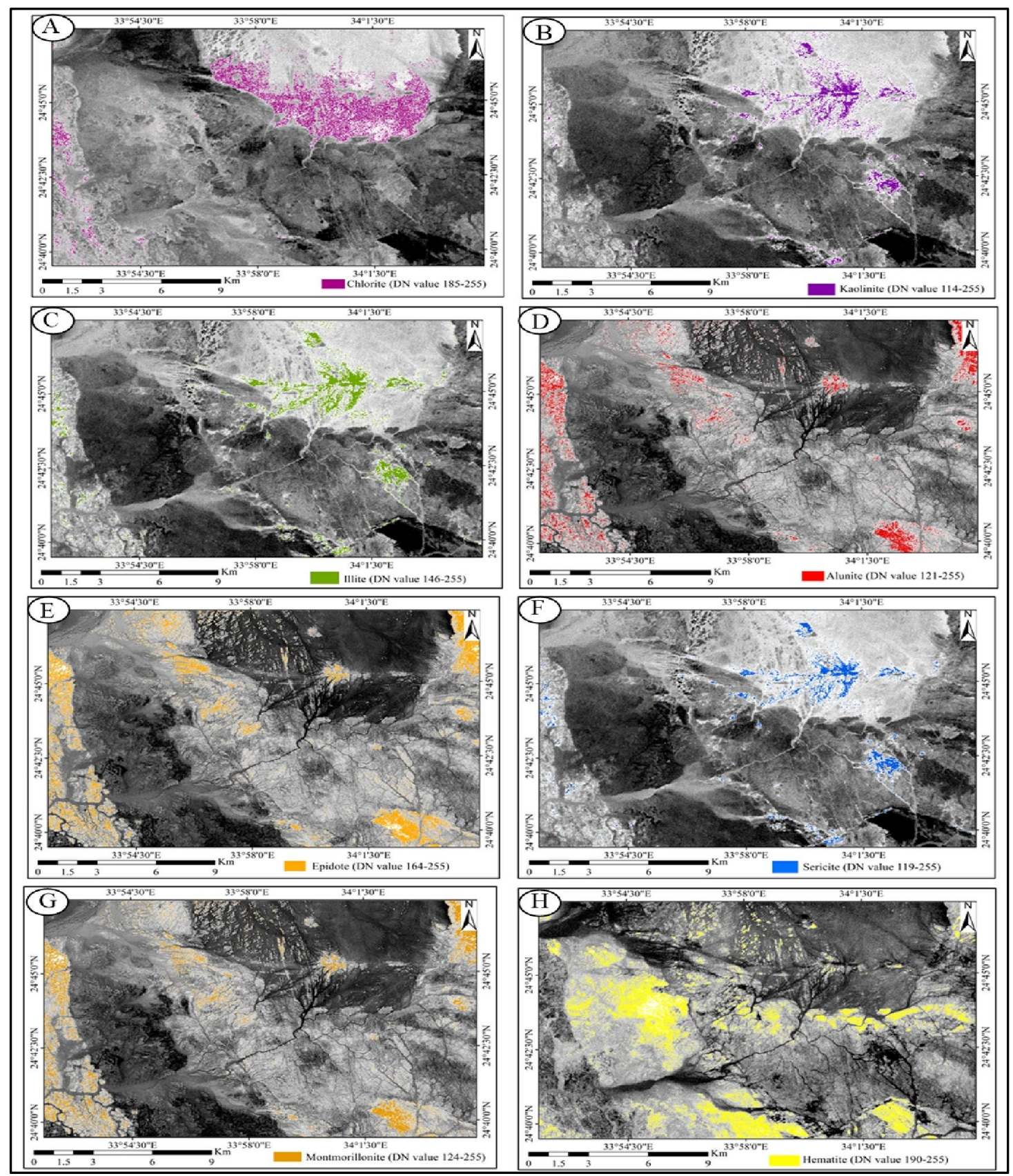

Fig. 4: Crosta technique for the input VNIR SWIR bands: (A) PC3 Chlorite image. (B) PC3 Kaolinite image. (C) PC3 Illite image (D) PC2 Alunite image (E) PC3 Epidote image. (F). PC3 Sericite image (G) PC2 Montmorillonite image. (H) PC3 Hematite image. 
Table. 2: Statistics for selected ASTER bands.

\begin{tabular}{|c|c|c|c|c|}
\hline \multicolumn{5}{|c|}{ Chlorite } \\
\hline PC & Band 1个 & Band $2 \downarrow$ & Band $5 \uparrow$ & Band $8 \downarrow$ \\
\hline PC1 & 0.990881 & 0.049475 & 0.081323 & 0.095363 \\
\hline PC2 & -0.031844 & -0.988714 & -0.053892 & 0.136110 \\
\hline PC3 & -0.072453 & -0.036411 & 0.990534 & 0.110754 \\
\hline PC4 & -0.109049 & -0.136641 & 0.096560 & -0.979854 \\
\hline \multicolumn{5}{|c|}{ Kaolinite } \\
\hline $\mathbf{P C}$ & Band $4 \uparrow$ & Band $6 \downarrow$ & Band $7 \uparrow$ & Band 9 $\downarrow$ \\
\hline PC1 & 0.995366 & 0.052913 & 0.079689 & 0.009851 \\
\hline $\mathrm{PC} 2$ & 0.061878 & -0.990230 & -0.107524 & -0.063667 \\
\hline PC3 & 0.073411 & 0.112611 & -0.990902 & 0.073411 \\
\hline PC4 & -0.005391 & -0.062952 & -0.014227 & -0.005391 \\
\hline \multicolumn{5}{|c|}{ Illite } \\
\hline PC & Band $4 \uparrow$ & Band $6 \downarrow$ & Band $7 \uparrow$ & Band $8 \downarrow$ \\
\hline PC1 & 0.995203 & 0.040453 & 0.087257 & 0.017911 \\
\hline $\mathrm{PC} 2$ & 0.055246 & -0.980995 & -0.182588 & -0.035480 \\
\hline PC3 & -0.077554 & -0.187734 & 0.978561 & 0.034052 \\
\hline PC4 & 0.022457 & -0.027727 & -0.038290 & 0.998629 \\
\hline \multicolumn{5}{|c|}{ Alunite } \\
\hline PC & Band $3 \uparrow$ & Band $5 \downarrow$ & Band $7 \uparrow$ & Band 9 $\downarrow$ \\
\hline PC1 & 0.998200 & 0.043380 & 0.027955 & 0.030539 \\
\hline PC2 & 0.041261 & -0.997618 & 0.050712 & 0.022022 \\
\hline PC3 & 0.029564 & -0.049138 & -0.998206 & 0.017239 \\
\hline PC4 & -0.031929 & 0.021510 & 0.015250 & 0.999142 \\
\hline \multicolumn{5}{|c|}{ Epidote } \\
\hline $\mathbf{P C}$ & Band $5 \uparrow$ & Band $3 \downarrow$ & Band $6 \uparrow$ & Band $8 \downarrow$ \\
\hline PC1 & 0.997712 & 0.066639 & 0.010978 & 0.003041 \\
\hline PC2 & -0.066090 & 0.996824 & 0.044429 & -0.000270 \\
\hline PC3 & -0.013934 & 0.043601 & -0.998900 & 0.010168 \\
\hline PC4 & -0.002910 & -0.000376 & 0.010202 & 0.999944 \\
\hline \multicolumn{5}{|c|}{ Sericite } \\
\hline PC & Band $4 \uparrow$ & Band $6 \downarrow$ & Band $7 \uparrow$ & Band $8 \downarrow$ \\
\hline PC1 & 0.995203 & 0.040453 & 0.087257 & -0.017911 \\
\hline $\mathrm{PC} 2$ & 0.055246 & -0.980995 & -0.182588 & -0.035480 \\
\hline PC3 & -0.077554 & -0.187734 & 0.978561 & 0.034052 \\
\hline PC4 & 0.022457 & -0.027727 & -0.038290 & 0.998629 \\
\hline \multicolumn{5}{|c|}{ Montmorillonite } \\
\hline PC & Band $3 \uparrow$ & Band $6 \downarrow$ & Band $7 \uparrow$ & Band $9 \downarrow$ \\
\hline PC1 & 0.998260 & 0.041040 & 0.027158 & 0.032475 \\
\hline $\mathrm{PC} 2$ & 0.039096 & -0.998041 & 0.042628 & 0.023838 \\
\hline PC3 & 0.027423 & -0.040525 & -0.997886 & 0.042765 \\
\hline PC4 & -0.034583 & 0.024233 & 0.040847 & 0.998273 \\
\hline \multicolumn{5}{|c|}{ Hematite } \\
\hline $\mathbf{P C}$ & Band $2 \uparrow$ & Band $3 \downarrow$ & Band $4 \uparrow$ & Band $9 \downarrow$ \\
\hline PC1 & 0.997459 & -0.037697 & -0.058401 & -0.015632 \\
\hline $\mathrm{PC} 2$ & -0.041796 & -0.996412 & -0.073057 & 0.008871 \\
\hline PC3 & 0.055476 & -0.075309 & 0.995614 & 0.001889 \\
\hline PC4 & 0.015861 & 0.008393 & -0.002146 & 0.999837 \\
\hline
\end{tabular}

\subsubsection{Constrained Energy Minimization (CEM) technique}

This technique enabled us to identify the distribution of eight alteration minerals from the ASTER VNIR-SWIR surface reflectance data, these minerals are alunite, illite, chlorite, kaolinite, montmorillonite, epidote, hematite, and sericite. The spectral signatures of these alteration minerals are used from the USGS spectral library embedded in the ENVI v.5.3 software (Fig. 5), after reconfiguring them to match the VNIR-SWIR spectral bands of ASTER data (Fig. 6).

This technique resulted in the abundance of the spatial distribution of these eight alteration minerals in the satellite image enabling to map the alteration zones in the study area (Figs. 7). The 
alteration types and/or localities delineated using CEM is matched with hydrothermally altered rocks that are formerly enhanced by Crosta-Moore technique (FPCA).

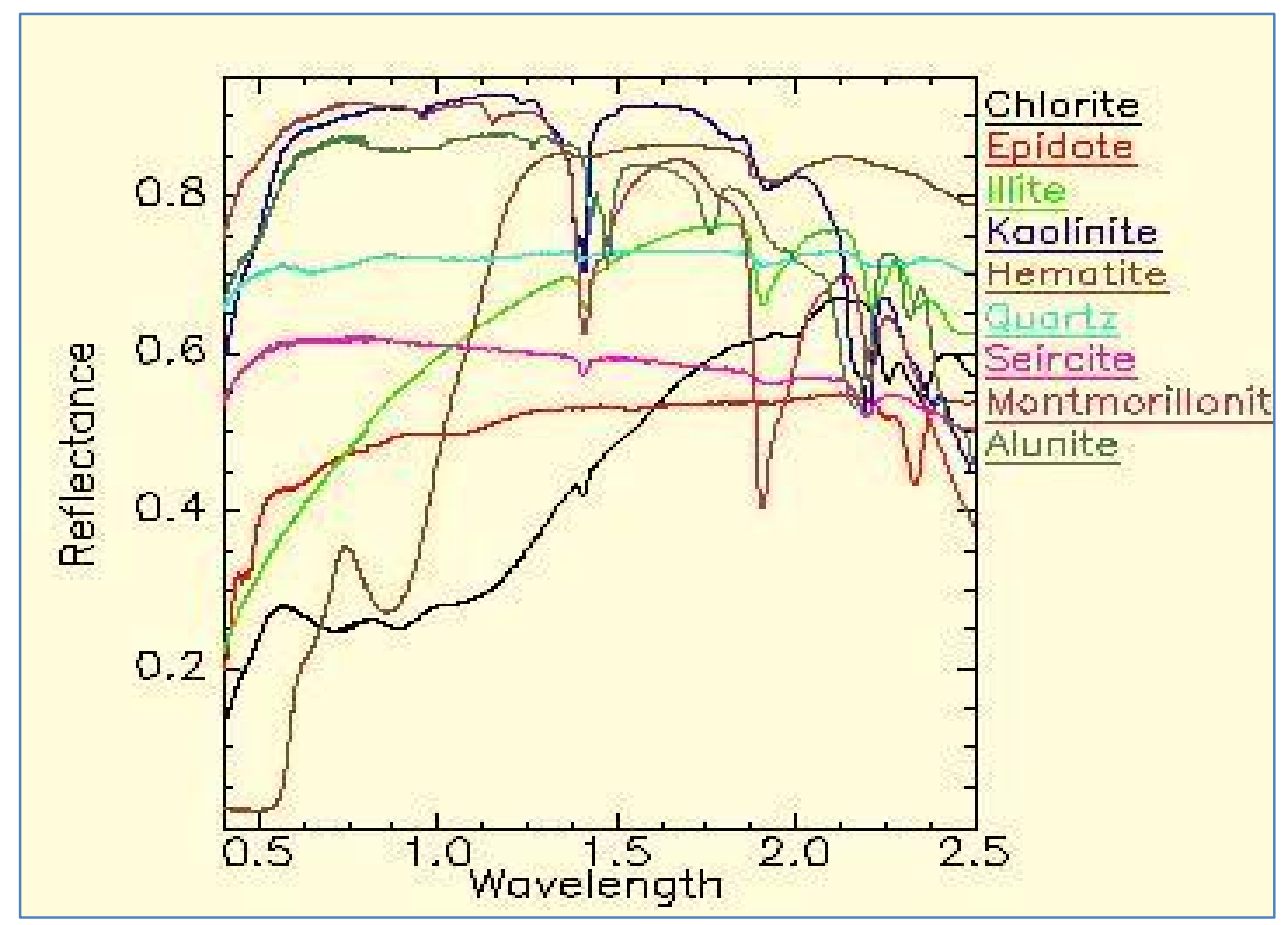

Fig. 5: The USGS library spectra of the ten studied minerals

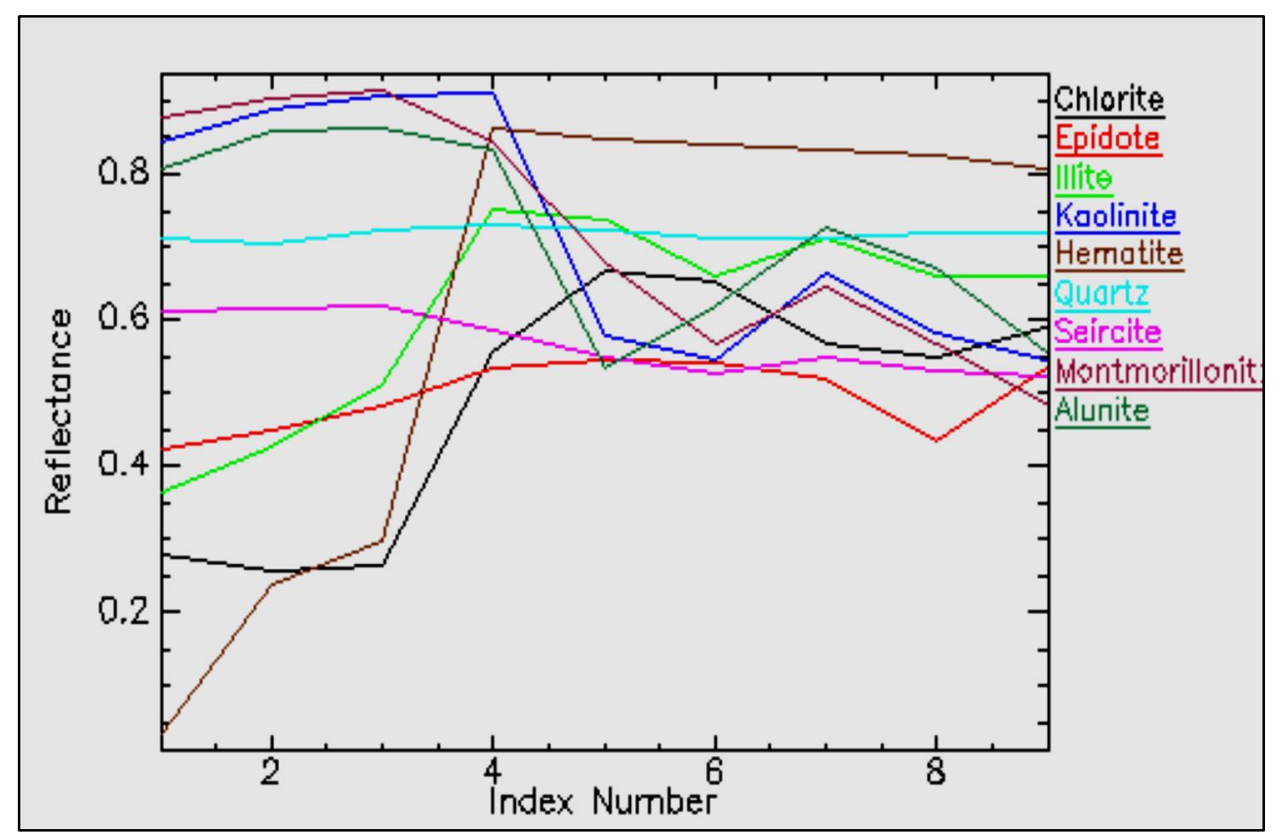

Fig. 6: ASTER VNIR-SWIR spectral signatures of endmember minerals spectra used in CEM method, measured by spectrometer in the field. 

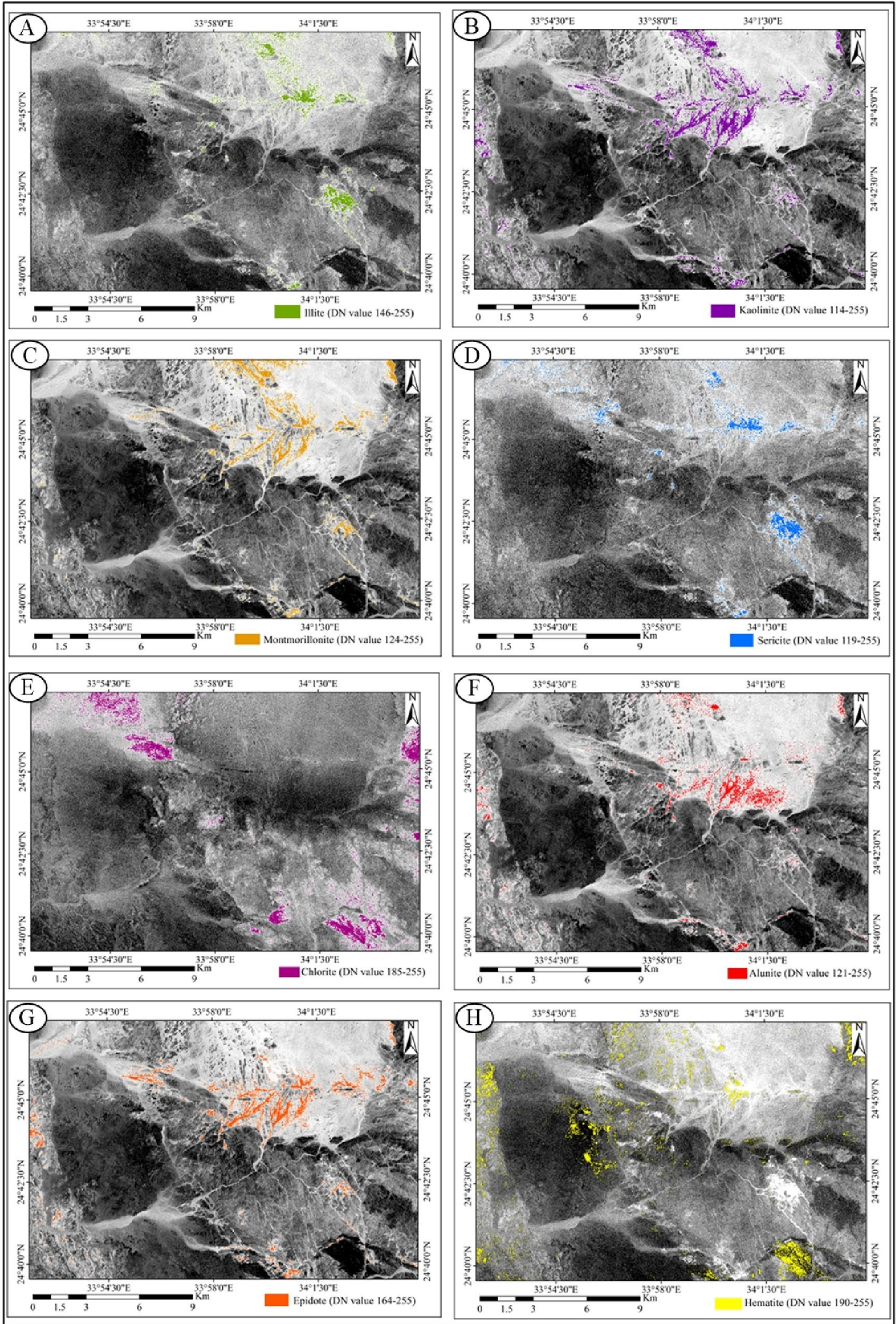

Fig. 7: Separated CEM classification endmember (illite, kaolinite, sericite, chlorite, alunite, montmorillonite, epidote, and hematite,) using VNIR-SWIR stack and the USGS ASTER resampled a spectral library. 


\subsubsection{Spectral ratio indices}

$\mathrm{OH}$-bearing altered minerals, mainly kaolinite, alunite, and montmorillonite, are characterized by an absorption feature in band 6, resulting in high reflectance in band 4 and 7 and relatively low reflectance in band 6 . Kaolinite has also an absorption feature in band 5, whereas alunite has absorption features in both band 5 and 8 . Calcite is characterized by a strong and clear absorption feature in band 8 and a weak peak in band 5 (Ninomiya, 2003).

The results of applying this technique on the nine VNIR-SWIR ASTER data of the study area is presented in (Fig.8) for the distribution abundance of Kaolinite, OH-bearing minerals, and Calcite indices, respectively. By comparing the results of the three techniques (Crosta, CEM and spectral ratio indices) used for alteration mapping; it is obtained that the locations of alterations delineated by all the three techniques are the same and this supports the results one by another.

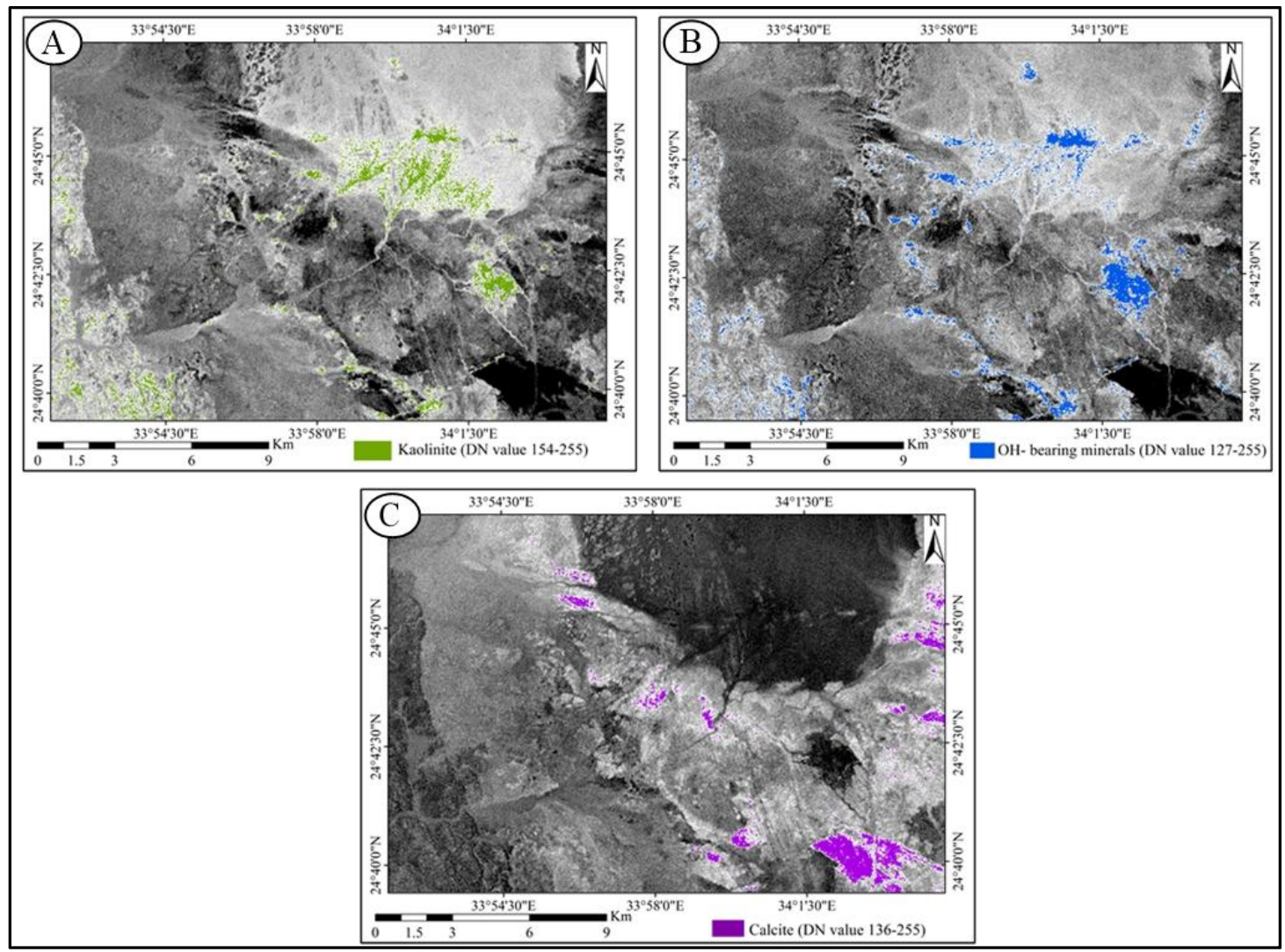

Fig. 8: (A) kaolinite, (B) OH-bearing minerals, and (C) calcite mapping using spectral ratio indices overlying spectral ratio image

\subsubsection{Lineament extractions and lineament density}

In this study, automatic lineament extraction has been carried out using the most widely used software for such purpose (the LINE module of the PCI Geomatica package using the default parameters to adjustment of the Edge gradient threshold to 40 pixels). The algorithm of extraction consists of edge detection, thresholding, and linear extraction steps. ASTER VNIR-SWIR spectral bands and Principal Component bands have been tested to select the best band for lineament extraction.

Results indicated that the best band for automatic lineament extraction is the first Principal Component band (PC1). The automatically extracted lineaments are shown in (Fig.9-A) after being edited for the elimination of the man-made features.

In this research, we calculated the lineament density (Fig. 9-B) automatically using Arc GIS v. 10.3. Based on the number of lines per unit area (number $/ \mathrm{km}^{2}$ ). The resulting lineament density map is then determined using the same program, in the lineament contour map (Fig. 9-C).

The highest densities are represented in red and are assumed to represent a higher level of fracturization in the rocks that are related to mineralization. Therefore, the coincidence of high-density lineaments and alteration zones indicate a high probability for the presence of mineralization. Thus, the 
lineament density map became more useful when it is combined with other information regarding the alteration zones in the area which have been successfully mapped using several approaches (Crosta method, CEM and Spectral ratio index); thus we used the result of the CEM technique as that represents the spatial distribution of the alteration minerals Accordingly, we can identify the most potential areas of mineralization taking us into consideration the overlapping of high lineament density areas with abundant alterations (Fig. 9-D).

The directional analysis of the automatically extracted lineament maps (Fig. 9-A) and rose diagram explained (Fig.9-E) that there are main faulting trends that have been recognized that are NWSE, NNE-SSW and N-S (in descending manner).

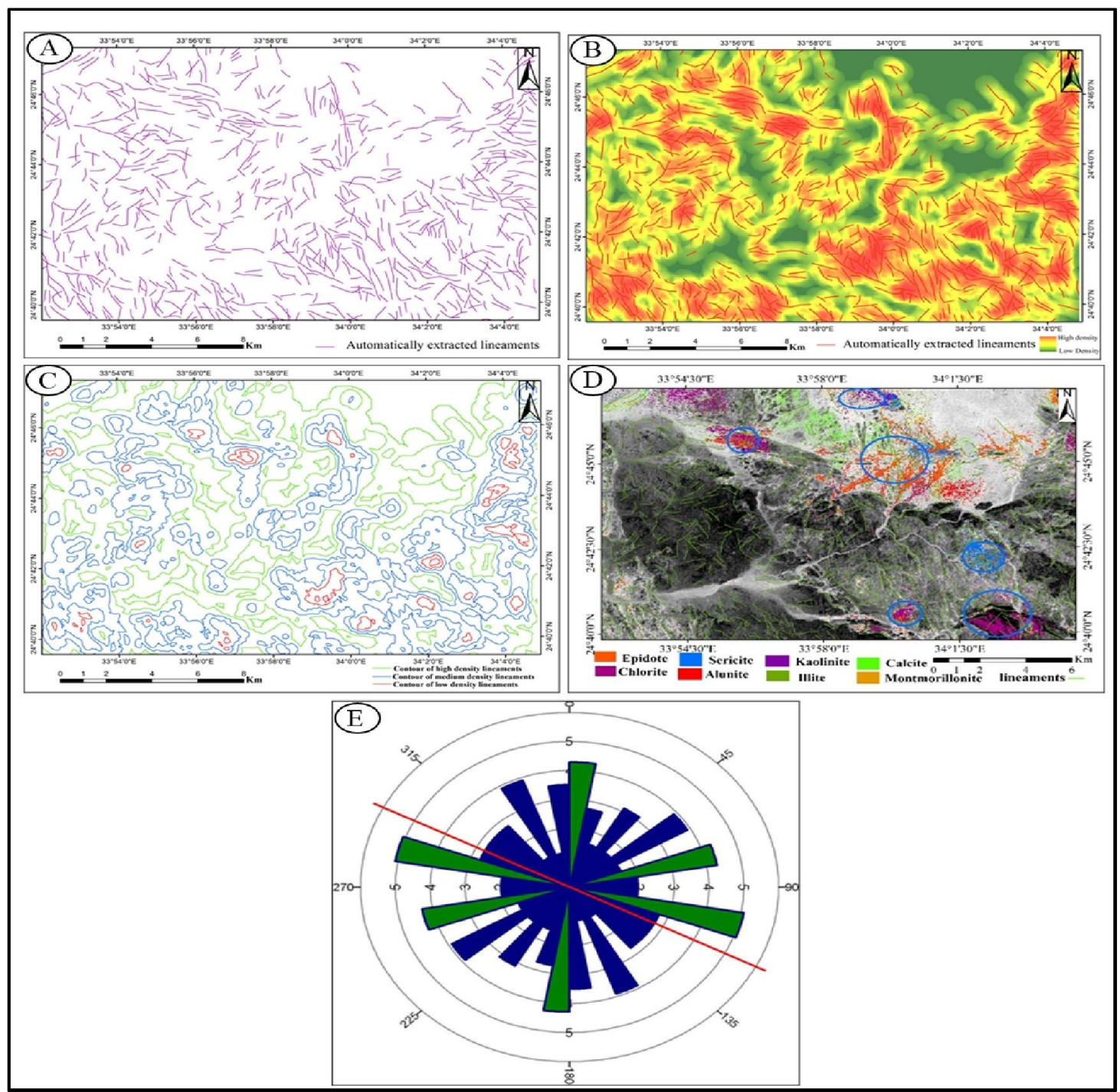

Fig. 9: (A) Automatically extracted lineaments from the ASTER image using PCI geomatica software.

(B) Lineament density map.

(C) Lineament contouring map, higher densities are represented by red color.

(D)Lineaments density contour overlying the Alteration zones obtained by the CEM technique all the layers are overlying ASTER band 4.

(E) Directional analysis (rose diagram) of lineament frequencies and that of lineament lengths of Wadi Sibrit and Urf Abu Hamam area, South Eastern Desert Egypt.

\subsection{Host rocks and their hydrothermal alteration processes}

The studied rock units show different degrees of hydrothermal alterations such as sericitization, chloritization, muscovitization, epidotization, silicification, saussuritization, carbonatization, kaolinitization, ferrugination and lateritization. The stages of hydrothermal activity can be linked to the tectonic evolution of the study Wadi Urf Abu Hamam and Wadi Sibrit district. 
Sericitization is one of the most common types of hydrothermal alteration found in felsic rocks (Creasey, 1966; Meyer and Hemely, 1967; Rose, 1970 and Lowell and Guilbert, 1970). It is a product of sericitization of oligoclase, albite and microcline. Sericite is recorded in altered rocks such as andesites (Fig. 10A), tuffs and alkali feldspar granites.

Chloritization, Chlorite is recorded in altered metabasalts, quartz diorites, andesites (Figs.10B) hornblende granites (Fig.10C), quartz monzogranites and alkali feldspar granites. Secondary chlorite occurs between the interstitial spaces of hornblende, plagioclase, and quartz. Chlorite is generally derived from the partial or total replacement of primary biotite, hornblende, and pyroxene. Muscovitization, the recorded muscovite is mainly after plagioclase and it is recorded in the altered rhyolites (Fig.10D) and represented by large crystals occupying the interstitial spaces between plagioclase. Epidotization (propylitic), Epidotization is recorded in the altered metabasalts, metagabbros, rhyolites, quartz porphyry (Fig.10E), quartz monzogranites and altered olivine doleritic basaltic dykes (Fig.10F). They are mainly manifested by partially altered plagioclase and K-feldspars. Silicification, formation of quartz rocks and the comb quartz bands in the contact of the altered Wadi Urf Abu Hamam and Wadi Sibrit granite intrusion produce silicification. In the studied samples silicification is recorded in altered andesite porphyry and tuffs (Fig.10G). Saussuritization, the saussuritization are recorded in altered quartz diorites (Fig.10H), andesite porphyry, hornblende granites, quartz monzogranites and alkali feldspar granites. Carbonatization process derived from direct capture of $\mathrm{CO}_{2}$ from near-surface fluids and reacted with silicate minerals in the studied rhyolites and alkali feldspar granites. Carbonatization process found in the altered rhyolites (Fig.10I), tuffs and alkali feldspar granites. Ferrugination (Hematitization), Ferrugination is red, reddish-brown, and yellowish red in color, and may cement to form subsurface iron rust in alteration oxidation zones at Wadi Sibrit.
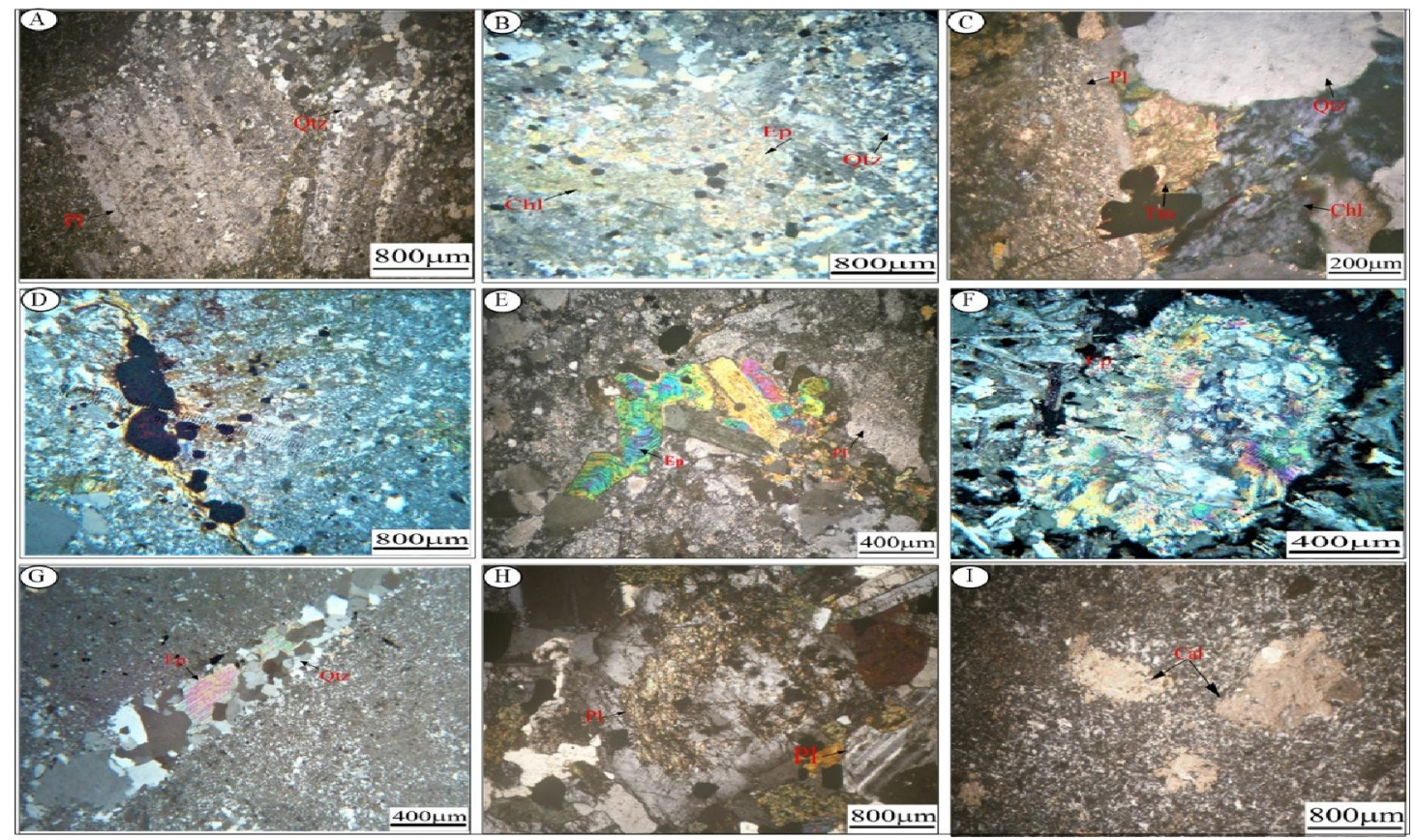

Fig. 10: Photomicrograph showing:(A) Phenocryst of plagioclase (Pl) altered to sericite set in finegrained groundmass of quartz (Qtz) and epidote with secondary quartz. C.N. (B) Well-developed crystals of epidote (Ep) and chlorite (Chl) associated with quartz grains. C.N. (C) Secondary titanite associated with chlorite. C.N. (D) Phenocrysts of opaque minerals and muscovitization (Ms) of plagioclase. C.N. (E) Well-developed crystals of epidote (Ep). C.N. (F) Well-developed crystals of epidote filling the amygdales. C.N.(G) Microveinlets filled with secondary quartz (Qtz) and epidote (Ep). C.N. (H) Highly altered plagioclse (Pl) showing saussuritization. C.N. (I) Phenocrysts of carbonate $(\mathrm{Cal})$ embedded in the groundmass. C.N.

The deep reddish-brown color mostly characterizes the strongly hematitization in alteration zones and altered granites. Ferrugination process is the dominant hydrothermal process and occupies the main Wadi Sibrit alteration zones (Fig. 11). Ferrugination is related to oxidation of magnetite and 
ferromagnesian minerals to hematite in slightly alkaline environment. Lateritization, the lateritization process occurs because Natash volcanics exposed at the surface is subjected to weathering, but the degree of alteration diminishes with depth, so producing a laterite weathering profile. Ferricretes is recorded in Natash volcanics, which contain high iron content through residual enrichment, and accumulation of allochthonous iron into a host rock or existing weathering profile (Fig.12).

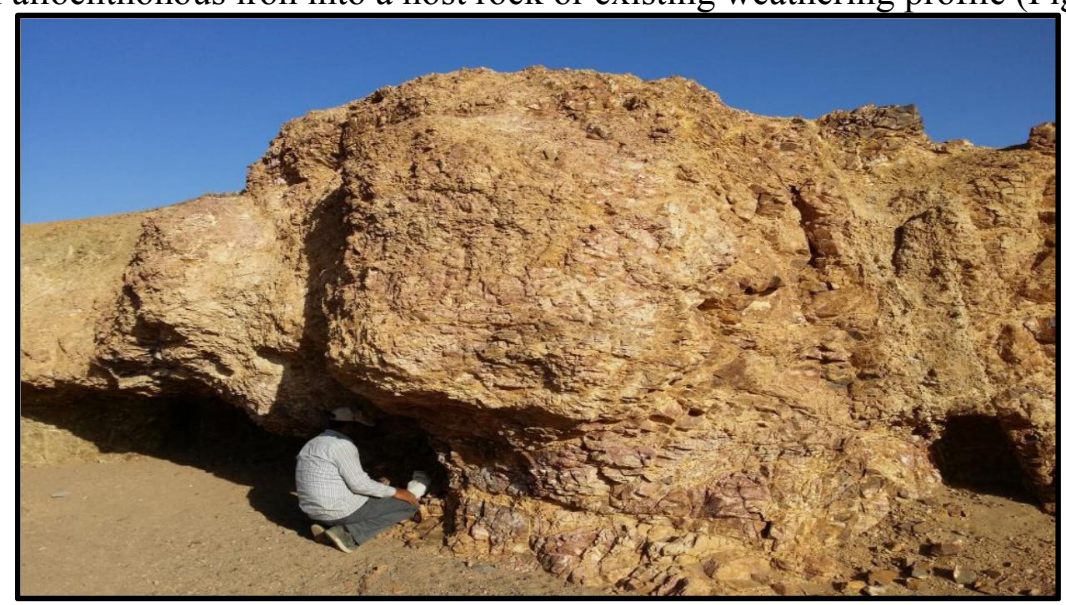

Fig. 11: Photograph showing the ferrugination and carbonatization hydrothermal processes in Wadi Sibrit alteration zones, looking SW.

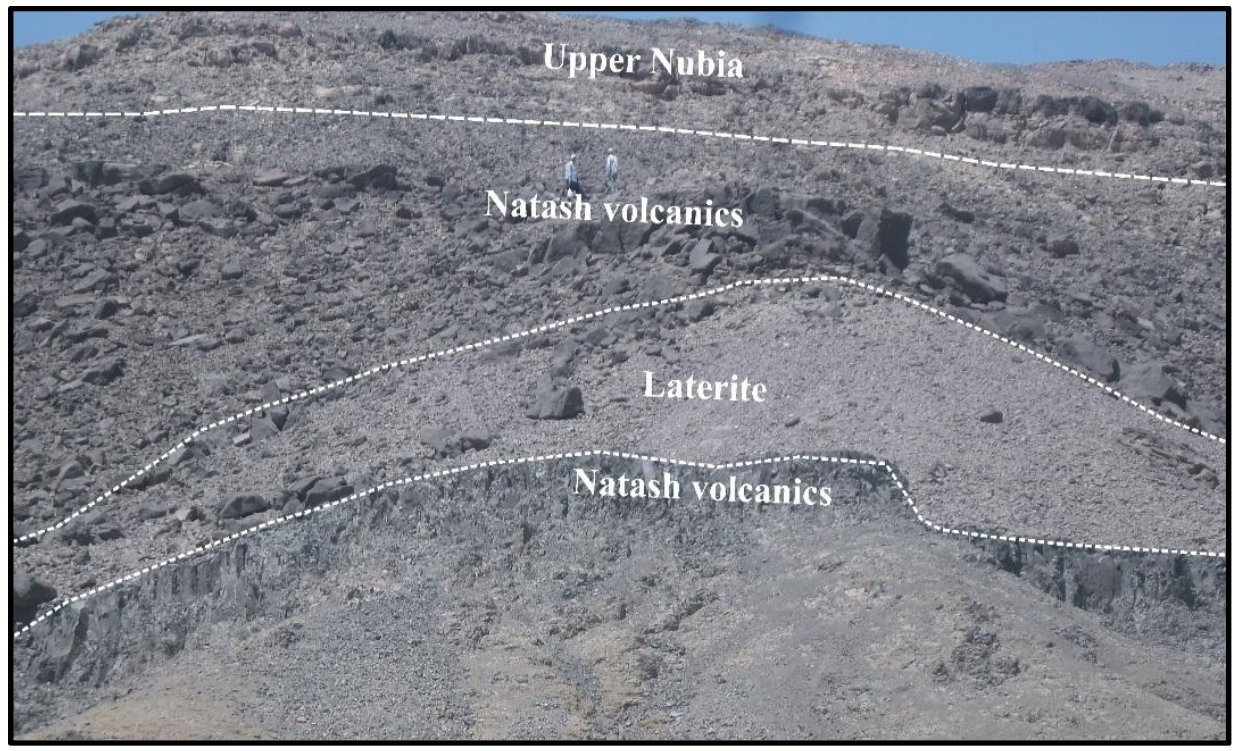

Fig.12: Photograph showing two sheets of Natash volcanics with laterite deposits at Wadi Sibrit district, looking W.

\subsection{Ore microscopic study}

A detailed study of the mode of occurrence, textures and their specific petrographic features of both ore metals and gangue minerals in the collection samples of Wadi Sibrit and Urf Abu Hamam district. The examined thin-polished sections exhibit that they contain pyrite, galena, ilmenite, magnetite, martite, and goethite.

The ore is found to be composed of the hypogene (endogenic) sulfide and oxide minerals. Secondary supergene minerals include martite, and goethite. Sulfide minerals are represented by pyrite, chalcopyrite, and galena occurs in the alteration zones and mineralized quartz veins.

Pyrite (Cubic - hexahedron) Pyrite cubes and pyramidal crystals were recorded in the Urf Abu Hamam mineralized quartz veins, altered rhyolites, and in Wadi Sibrit mineralized alteration zones (Fig. 13.A). Sometimes, the coarse-grained pyrite crystals reveal progressive stages of alteration in which the crystals are slightly to moderately altered to goethite (Fig.13.B). In some cases, it they are completely altered to goethite (Fig.13.C). 
Chalcopyrite (Tetragonal), Chalcopyrite is present as few crystals associated with pyrite in Urf Abu Hamam mineralized quartz veins. Chalcopyrite is brassy yellowish in color and forms fine anhedral aggregates with grain sizes vary from 0.07 to $1.7 \mathrm{~mm}$. It was appearing particularly in the green copper oxide staining the mineralized quartz veins (Fig.13.D). In some specimens, chalcopyrite crystals may be oxidized to copper oxides along fractures and microfissures.

Galena (Hexoctahedral), galena occurs as fine- to medium-grained and subhedral crystals (Fig.13.E). Galena is bright white in color with high reflectivity, isotropic and it is less often partially replaced by cerussite. The grain size ranges between 0.13 and $0.43 \mathrm{~mm}$. Occasionally, it appears as fine grains associated with magnetite and disseminated fine specks in the altered quartz porphyry, andesites, and rhyolites (Fig.13.F). Galena is present in the form of irregular patches, and is intimately associated with pyrite and gangue minerals, showing intergranular texture.

Iron oxides minerals are represented by magnetite, ilmenite, and goethite (as iron hydroxides). Magnetite (Cubic - octahedron), in most of the studied slabs, magnetite is altered to martite that occurs as a secondary mineral due to the oxidation of magnetite to hematite at Wadi Sibrit mineralized alteration zones.

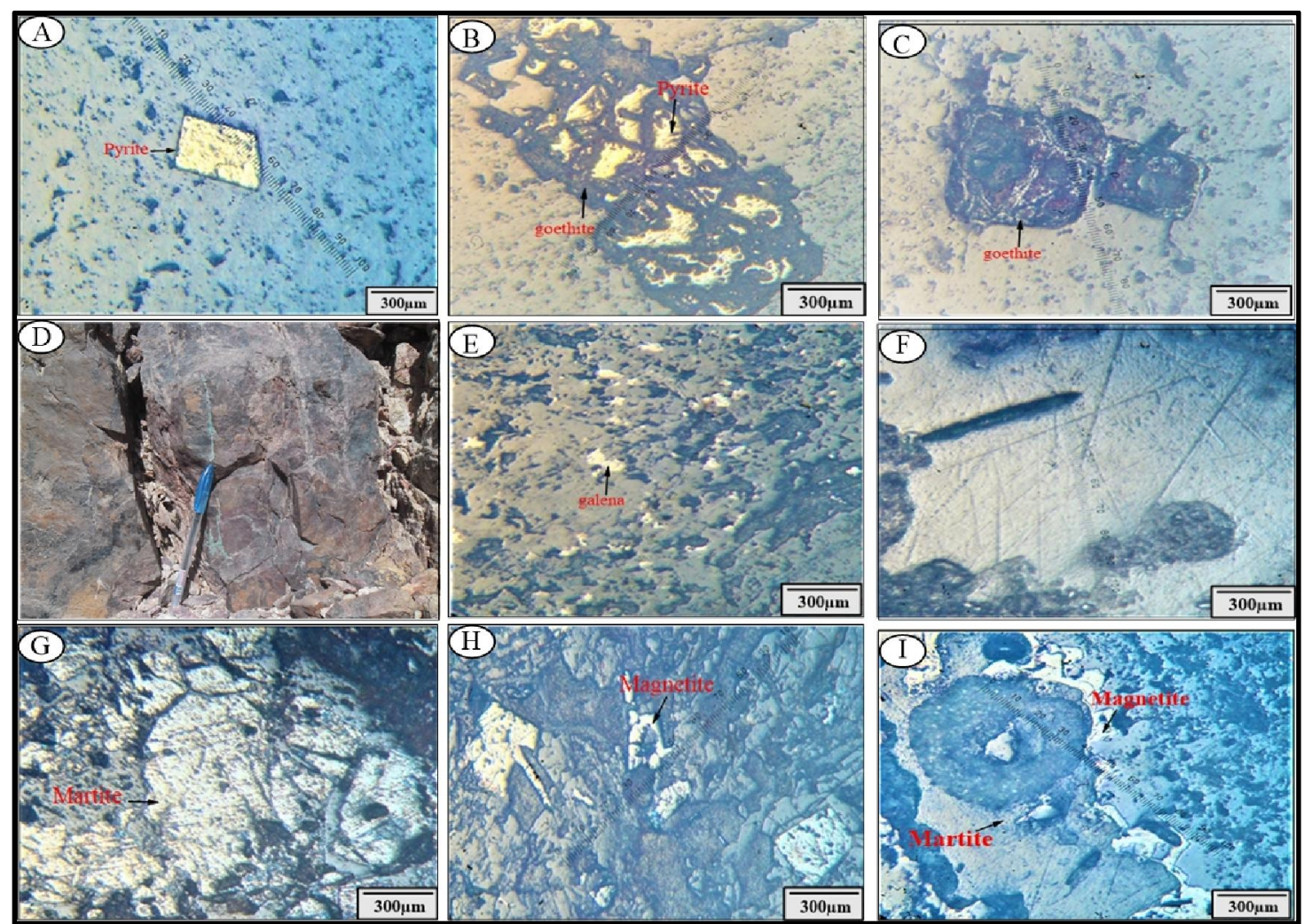

Fig.13: Photograph showing: (A) Coarse-grained fresh cubic pyrite crystals of Urf Abu Hamam mineralized quartz veins (R.P.L) (B) Pyrite crystals which partially altered to goethite of the mineralized quartz veins (R.P.L) (C) Mineralized quartz veins shows cubic pyrite crystals completely altered to goethite (R.P.L) (D) Mineralized quartz veins impregnated by green copper oxides, Wadi Urf Abu Hamam district (E) Galena crystals along the pyrite fine grains groundmass (R.P.L) (F) Galena characterized by three sets of cleavages in altered rhyolite ((R.P.L) $(\mathrm{G})$ polished surface from the altered rhyolite shows lamellae martite crystals (R.P.L) (H) polished surface from the altered olivine doleritic basalts shows coarse-grained magnetite (R.P.L) (I) amorphous solution of martite after magnetite (R.P.L) (j) polished surface from the mineralized alteration zones shows pseudomorphic cubes of goethite after pyrite (R.P.L) (K) polished surface from the altered rhyolite shows goethite filling interspatial spaces (R.P.L).

Magnetite is mostly common in mineralized rhyolite and alteration zones; it exhibits light grey color and moderate reflectance. It appears as anhedral crystals, which exhibit a regular martitization along octahedral planes and an irregular martitization along grain boundaries and cracks (Fig.13.G). 
Magnetite is usually fresh (Fig.13.H) but may be completely altered to hematite (martite) where martitization could be regular or irregular. In the regular martitization, the octahedral cleavage planes (111) are followed, producing a triangular network of hematite lamellae (Fig. 13.G). In the mineralized alteration zones, martite occurs as amorphous solution along cracks (Fig.13.I) Goethite mineral is predominant iron hydroxide occurs in the oxidized zones and Urf Abu Hamam quartz veins (Fig.13.C). It is occurring mainly as alteration product replacing the Fe-bearing sulfides in the different mineralized alteration zones. It occurs as coarse grains associating massive crystal aggregates and pseudomorphic cubes after pyrite.

\subsection{Alteration mineralogy}

The mineralogical investigations aim to identify the mineral assemblages of the mineralized altered rocks and quartz veins at the study district. The ore minerals have been studied in detail by using $\mathrm{X}$ - ray diffraction. Ten representative samples were analyzed from the mineralized quartz veins, alteration zones and different mineralized altered rocks, as shown in the X-ray diffraction charts (Fig. 14). Minerals of the altered zone in the detected samples include quartz, albite, chamosite, goethite, calcite, epidote, illite, lepidolite, muscovite, tremolite-ferroactinolite, clinochlore, dolomite. The ore minerals in the investigated altered rocks and mineralized alteration zones are represented by iron oxides such as hematite, goethite, chamosite, and magnetite in the fissures and fractures and its wall rock alteration.
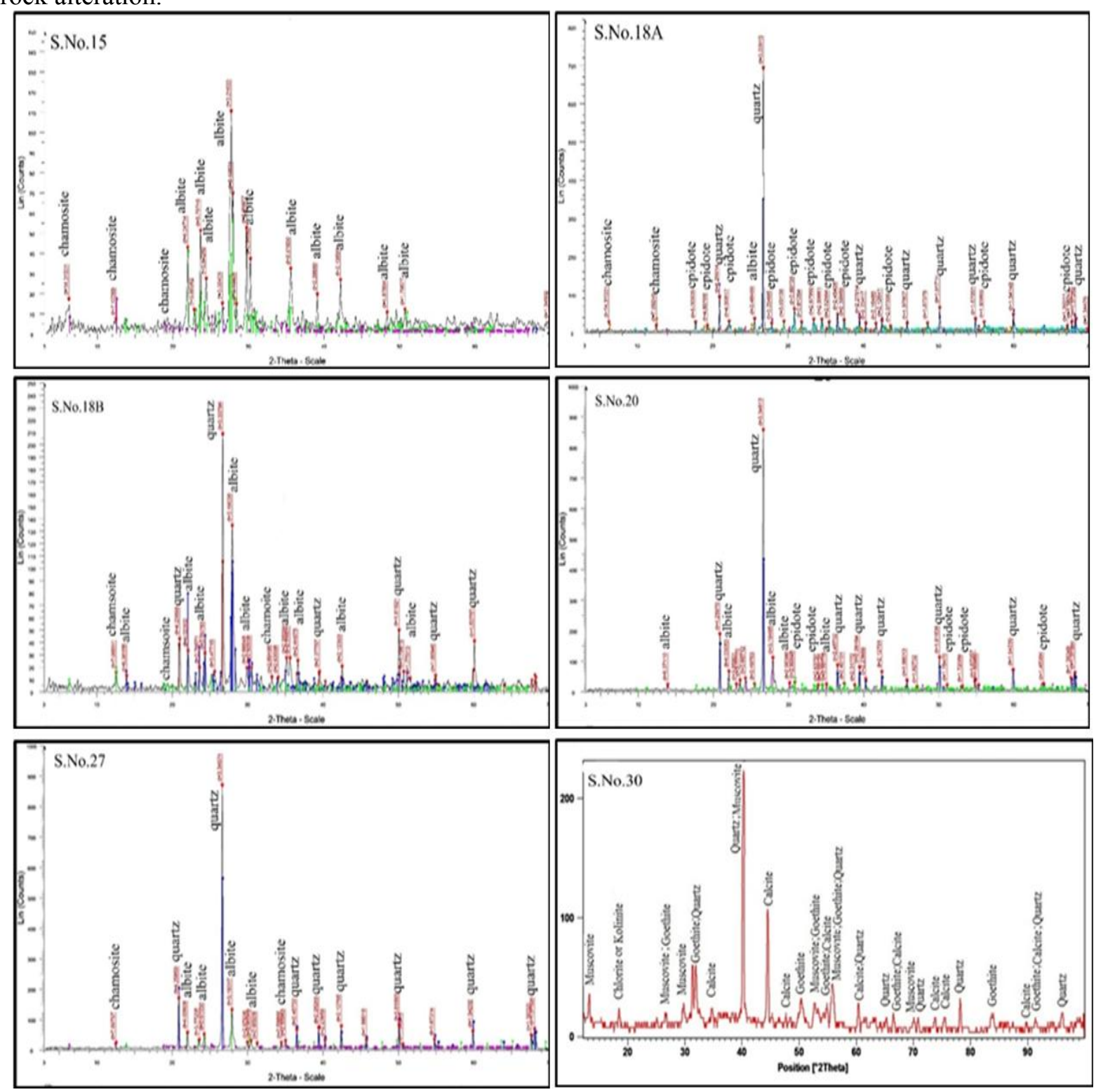

Fig.14: X-ray diffraction patterns of the studied rocks. 
Chamosite is a product of hydrothermal alteration of pyroxenes, amphiboles, and biotite in igneous rocks. It is produced in an environment low to moderate grade of metamorphosed iron deposits. As other chlorite, more Fe-rich chlorites are commonly found as replacements of Fe-rich ferromagnesian minerals (Deer et al., 1992).

\subsection{Chemistry of some mineral deposits (SEM/EDX)}

The investigation slabs of the specimens from the different rock units of Wadi Sibrit and Urf Abu Hamam by using SEM/EDX reveals the presence of pyrite, chalcopyrite, ilmenite, rutile, magnetite, goethite, barite, zircon, thorite, monazite, eskolaite, jarosite, and orlite.

The results obtained about the mineral investigation detected the following mineral association: Pyrite represents the main sulfide minerals in the studied samples and is mainly altered to goethite. (Figure.15 A) shows the X-ray spectrum analysis of pyrite within thin polished surface taken from Urf Abu Hamam mineralized quartz veins. Chalcopyrite $\left(\mathrm{CuFeS}_{2}\right)$ recorded as idiomorphic coarse-grained crystals. (Figure $15 \mathrm{~B}$ ) shows the X-ray spectrum analysis of chalcopyrite within polished surface taken from the Urf Abu Hamam mineralized quartz veins.

Ilmenite $\left(\mathrm{FeTiO}_{2}\right)$, ilmenite was found predominant within Wadi Sibrit altered doleritic basalts and Wadi Urf Abu Hamam mineralized quartz veins. The analyzed ilmenite crystals show high content of $\mathrm{TiO}_{2}$ reaches about $20.05 \%$ and $\mathrm{Fe}_{2} \mathrm{O}_{3}$ content of about 55.52\%. Meanwhile, the contamination with the host-rock caused presence of small peaks of $\mathrm{Na}_{2} \mathrm{O}(1.71 \%), \mathrm{MgO}(1.68 \%), \mathrm{Al}_{2} \mathrm{O}_{3}(6.03 \%), \mathrm{SiO}_{2}$ $(11.05 \%), \mathrm{CaO}(0.49 \%), \mathrm{K}_{2} \mathrm{O}(1.84 \%)$, and $\mathrm{MnO}(1.62 \%)$ along the spectrum profile of ilmenite (Fig.15C).

Rutile $\left(\mathrm{TiO}_{2}\right)$, rutile more often forms rounded toll-like aggregates (Fig.15.D). Big rutile crystals may grow in pegmatites or hydrothermal quartz veins. Figure $(15 \mathrm{D})$ shows the X-ray spectrum analysis of rutile in the thin polished section surface of the mineralized alteration zones associated with ilmenite crystals.

Magnetite $\left(\mathrm{Fe}_{3} \mathrm{O}_{4}\right)$, magnetite ore mineral was recorded by microscopic investigation and assured by SEM and EDX investigations. Figure (15.E) illustrates the spectrum profile obtained from X-ray and microchemical analysis of magnetite polished surface taken from the altered olivine doleritic basalts.

Barite (BaSO4). The presence of barite was assured during the SEM and EDX investigations carried out on the thin-polished surfaces of Wadi Urf Abu Hamam mineralized quartz veins. The scan image shows barite crystals occurring as an accessory mineral in the metalliferous hydrothermal quartz veins and presents as fine-grained in the fractures and fissures (Fig.16 A).

Zircon $\left(\mathrm{ZrSiO}_{4}\right)$, zircon is occurring as euhedral six-sided or eight-sided form with clusters opaque inclusions. Figure (16 B) shows the X-ray spectrum obtained from the EDX microanalysis of Wadi Urf Abu Hamam mineralized alteration zones and Wadi Sibrit altered olivine doleritic basalts. Thorite $\left\{(\mathrm{Th}, \mathrm{U}) \mathrm{SiO}_{4}\right\}$, Thorite occurs as brown to black color crystals, medium, reniform fractured grained and subhedral to euhedral crystals (Fig. $16 \mathrm{C}$ ). It contains as much as $10 \%$ uranium (Heinrich, 1958).

Monazite $\left\{(\mathrm{Ce}, \mathrm{La}, \mathrm{Th}, \mathrm{Nd}, \mathrm{Y}) \mathrm{PO}_{4}\right\}$. In Wadi Urf Abu Hamam mineralized quartz veins, the analyzed monazite crystals display high peaks of lanthanum, cerium and neodymium (Fig. $16 \mathrm{D})$. In addition, small peaks of calcium $(0.66 \%)$, iron $(0.57 \%)$, uranium $(1.51 \%)$, praseodymium $(3.50 \%)$, samarium $(2.63 \%)$, gadolinium $(1.60 \%)$, thorium $(5.40 \%)$, and potassium $(0.25 \%)$ appear along the profile indicating presence of small amounts of these elements in monazite crystals. 

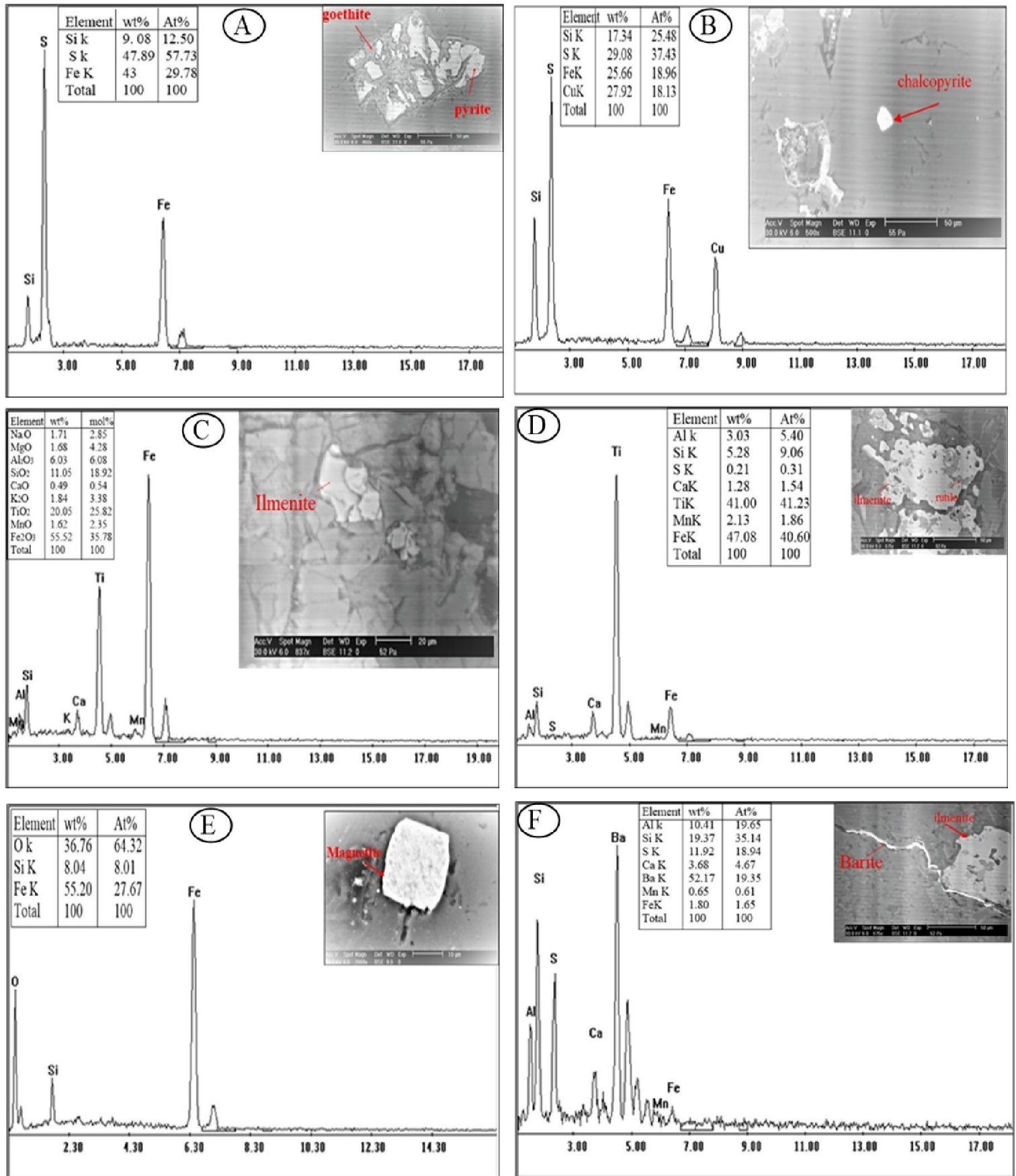

Fig. 15: X-ray spectrum profile showing: (A) High peaks of Fe and S. The scan image shows the analyzed pyrite grains, Wadi Urf Abu Hamam mineralized quartz veins. (B) High peaks of $\mathrm{Cu}, \mathrm{Fe}$, and S. The scan image shows the analyzed chalcopyrite grains, Wadi Urf Abu Hamam mineralized quartz veins. (C) High peaks of $\mathrm{Fe}$ and $\mathrm{Ti}$. The scan image shows the analyzed ilmenite grains, Wadi Sibrit altered olivine doleritic basalts. (D) High peaks of Fe and Ti. The scan image shows the analyzed rutile grains, Wadi Urf Abu Hamam mineralized quartz veins. (E) High peaks of Fe and O. The scan image shows the analyzed magnetite grains, the Wadi Sibrit altered olivine doleritic basalts. (F). high peaks of $\mathrm{Ba}$ and $\mathrm{S}$. The scan image illustrates the analyzed barite grains, Wadi Urf Abu Hamam mineralized quartz veins. 


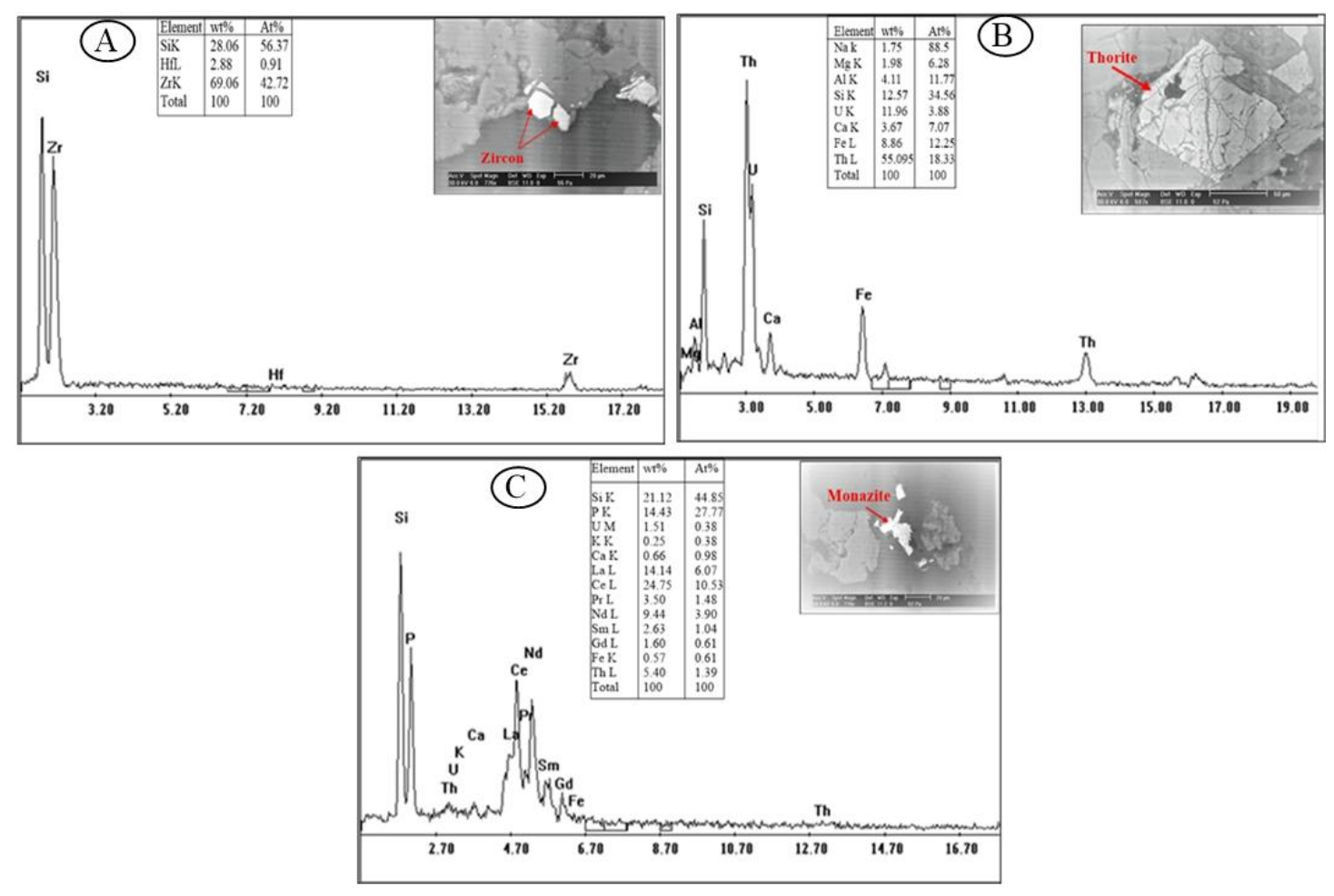

Fig.16: X-ray spectrum profile showing: (A). EDX and BSE micrograph showing crystals of zircon associating, Wadi Urf Abu Hamam mineralized alteration zones. (B). High peaks of Th, U, and Si. Scanning electron microscope back scatter images of trace minerals (Thorite) in Wadi Sibrit altered olivine doleritic basalts. (C). high peaks of $\mathrm{Ce}, \mathrm{Nb}, \mathrm{P}$ and $\mathrm{Si}$. Scanning electron microscope back scatters images of monazite crystal, Wadi Sibrit mineralized alteration zones.

\section{Discussion and Conclusion}

The integration between the remote sensing, field work, mineral study has been combined to identify and map the alteration zones as well as the structural lineaments at Wadi Sibrit - Wadi Urf Abu Hamam district, South Eastern Desert of Egypt. Several remote sensing techniques including Crosta principal Component (Crosta PC), Constrained Energy Minimization (CEM) and Spectral ratio indices have been integrated to extract these alterations from the ASTER data using ENVI v. 5.1 software.

The results revealed presence of several alteration zone related to the geological structural features at Wadi Sibrit - Wadi Urf Abu Hamam area. Sericitization, chloritization, muscovitization, epidotization, silicification, saussuritization, carbonatization, ferrugination and lateritization are the main alteration processes associating with altered minerals eg; chlorite, kaolinite, illite, alunite, epidote, iron oxides, sericite, montmorillonite, $(\mathrm{OH})$-bearing minerals and iron oxides. Pyrite, chalcopyrite, galena, magnetite, ilmenite, martite, goethite, chamosite, quartz, albite, calcite, epidote, illite, lepidolite, rutile, barite, zircon, thorite, monazite, spessartine and brookite minerals were detected by XRD and SEM techniques in the study area. By comparing the results of the different alteration mapping methods used in the present study, it is evident that the locations of alterations delineated by all the three techniques are more or less the same and this supports the results one by another. The results indicated that the best band for automatic lineament extraction is the first Principal Component band (PC1), these extracted lineaments were utilized in portraying most favorable areas of mineralization based on their density and coincidence on alteration parameters. Moreover, the highest lineaments densities are assumed to be valid mineralized sites in the host rocks.

Accordingly, we can identify the potential areas of mineral bearing hydrothermal alteration zones for mineral exploration, taking into consideration the overlapping of high lineament density areas with abundant alterations, and apply in the other regions. 


\section{References}

Abdeen, M.M., T.K. Allison, M.G. Abdelsalam, and R.J. Stern, 2001. Application of ASTER bandratio images for geological mapping in arid regions; the Neoproterozoic Allaqi Suture, Egypt. Abstract with Program Geological Society of America 3 (3): 289.

Abdelsalam, M.G., R.J. Stern, 1996. Sutures and shear zones in the Arabian-Nubian Shield. Journal of African Earth Sciences, 23: 289-310.

Abou El-Magd, I., H. Mohy, and F. Basta, 2015. Application of remote sensing for gold exploration in the Fawakhir area, Central Eastern Desert of Egypt, Arabian Journal of Geoscience. 8(6): 35233536.

Abrams, M., and S.J. Hook, 1995. Simulated ASTER data for geologic studies IEEE Trans. Geosci. Remote Sensing, 33(3): 692-699.

Abrams, M.J., D. Brown, L. Lepley, and R. Sadowski, 1983. Remote Sensing for Porphry Copper Deposits in Southern Arizona. Economic Geology, 78: 591-604

Abu El-Leil, I., N.M.A. Soliman, M.H. Bekiet, and M.S. Elhebiry, 2019. Enhancing multispectral remote sensing data interpretation for historical gold mines in Egypt: a case study from Madari gold mine. Arabian Journal of Geosciences 12(1). DOI:10.1007/s12517-018-4081-6.

Amer, R., T. Kusky, and A. El-Mezayen, 2012. Remote sensing detection of gold related alteration zones of Um Rus Area, Central Eastern Desert of Egypt. Adv Space Res 49. 121-134.

Arnous, M. O. 2011. Integrated remote sensing and GIS techniques for landslide hazard zonation: a case study Wadi Watier area, South Sinai, Egypt, J Coast Conserv., 15 (4): 477-497, DOI 10.1007/s11852-010-0137-9.

Arnous, M.O., and D.R. Green, 2011. GIS and remote sensing as tools for conducting geo-hazards risk assessment along Gulf of Aqaba coastal zone, Egypt, J Coast Conserv., 15(4): 457-475, DOI 10.1007/s11852-010-0136-x.

Bedini, E., 2011. Mineral mapping in the Kap Simpson complex, central East Greenland, using HyMap and ASTER remote sensing data. Adv Space Res 47. 60-73.

Carranza, E.J.M., and M. Hale, 2002. Mineral imaging with Landsat Thematic Mapper data for hydrothermal alteration mapping in heavily vegetated terrane. International Journal of Remote Sensing, 23: 4827-4852.

Craig, J.R., 2001. Ore -Minerals textures and the tales they tell. 2001The Canadian Mineralogist. 39: 937-956.

Creasey, S.C., 1966. Hydrothermal alterations. In Titley, S.R. and Hicks, C.L., (Eds.), Geology of the Porphyry Copper Deposits, Southwestern North America. University of Arizona Press, 51-74.

Crosta, A., and J. Moore, 1989. Enhancement of Landsat thematic mapper imagery for residual soil mapping in SW Minais Gerais atate, Brazil: a prospecting case history in Greenstone belt terrain, in: proceedings of the Seventh ERIM Thematic Conference. Remote sensing for Exploration Geology, 1173-1187.

Crosta, A.P., C.R. Souza Filho, F. Azevedo, C. Brodie, 2003. Targeting key alteration minerals in epithermal deposits in Patagonia, Argentina, using ASTER imagery and principal component analysis. Int. J. Remote Sens., 23: 4233-4240.

Deer, W.A., R.A. Howie, and J. Zussman, 1992. An introduction to the rock-forming minerals. Longman Group Limited, 696.

Di Tommaso, I., 2007. Rubinstein, N."Hydrothermal alteration mapping using ASTER data in the Infiernillo porphyry deposit, Argentina"Ore Geology Reviews. 32(1-2):275-290.

Edet, A.E., C.S. Okereke, S.C. Teme, and E.O. Esu, 1998. Application of remote sensing data to groundwater exploration: A case study of the Cross-River State, southeastern Nigeria. Hydrogeology Journal, 6: 393-404.

El-Gaby, S., F.K. List, and R. Tehrani, 1988. Geology, evolution and metallogenesis of the Pan-African Belt in Egypt. In: El-Gaby S, Greiling RO (eds) The Pan-African Belt of Northeast Africa and adjacent areas. Viewing and Sons, Braunschweig/Wiesbaden, 17-68

El-Ghrabawy, O., N. Soliman, and A. Tarshan, 2019. Remote sensing signature analysis of ASTER imagery for geological mapping of Gasus area, central eastern desert, Egypt. Arabian Journal of Geosciences (IF 1.327) Pub Date: 2019-06-26, DOI: 10.1007/s12517-019-4531-9. 
Elhebiry, M.S., M. Sultan, I. Abu El-Leil, A.E. Kehew, M.H. Bekiet, I. Abdel Shahid, N.M. Soliman, Z. Abotalib, and M. Emil, 2019. Paleozoic glaciation in NE Africa: field and remote sensingbased evidence from the South Eastern Desert of Egypt. International Geology Review. Int. Geol. Rev. 2020, 62: 1187-1204

Gad, S., and T. Kusky, 2006. Lithological mapping in the Eastern Desert of Egypt, the Barramiya area, using Landsat Thematic Mapper (TM). J. African Earth Sci. 44, 196- 202.

Garven, G., M.S. Appold, V.I. Toptygina, and T.J. Hazlett, 1999. Hydrogeologic modeling of the genesis of carbonate-hosted lead-zinc ores. Hydrogeology Journal, 7(1): 108-126

Gass, I.G., 1982. Upper Proterozoic (Pan-African) calc - alkaline magmatism in northeastern Africa and Arabia. In: Andesite and related rocks. R.S. Thorpe (ed.). Wiley and Sons, New York, 591609.

Gemail, K., N.M. Abd-El Rahman, B.M. Ghiath, and R.N. Aziz, 2016. Integration of ASTER and airborne geophysical data for mineral exploration and environmental mapping: a case study, Gabal Dara, North Eastern Desert, Egypt. Environmental Earth Sciences. 75:592. DOI 10.1007/s12665-016-5368-0.

Ghoneim, S.M., 2017. Gold Exploration at the Western Extinction of El Sid- Fawakhir Area, Central Eastern Desert, Egypt Using Remote Sensing and GIS Techniques. M. Sc. Thesis, Fac. Sci. Cairo Uni., Egypt.

Heinrich, E.W., 1958. Mineralogy and geology of radioactive raw materials. Mc-Graw Hill Book Company, Inc. New York, Toronto, London. 654.

Johnson, P.R., A. Andresen, A.S. Collins, A.R. Fowler, and H. Fritz, 2011. Ghebreab, W., Kusky, T., Stern, R. J., 2011. Late Cryogenian-Ediacaran history of the Arabian-Nubian Shield: A review of depositional, plutonic, structural, and tectonic events in the closing stages of the northern East African Orogen. Journal of African Earth Sciences, 61: 167-232.

Khan, S.D., and K. Mahmood 2008. The application of remote sensing techniques to the study of ophiolites. Earth.Sci. Rev., 89: 135-143.

Kröner, A., J. Krüger, and A.A.A. Rashwan, 1994. Age and tectonic setting of granitoid gneisses in the Eastern Desert of Egypt and south-west Sinai. Geologische Rundschau 83: 502-513.

Koike, K., S. Nagano, and M. Ohmi, 1995. Lineament analysis of satellite images using a Segment Tracing Algorithm (STA). Comput Geosci., 21(9):1091-1104.

Loughlin, W.P., 1991. Principal Component Analysis for alteration mapping. Photogrammetric Engineering and Remote Sensing, 57:1163-1169.

Lowell, J.D., and J.M. Guilbert, 1970. Lateral and vertical alteration - mineralization zoning in porphyry copper deposits. Econ. Geol., 65: 373 -408.

Mah, A., G.R. Taylor, P. Lennox and L. Balia, 1995. Lineament analysis of Landsat Thematic Mapper Images, Northern Territory, Australia; Photogram. Eng.Remote Sens. 61: 761- 773.

Mars, J.C., and L.C. Rowan, 2006. Regional mapping of phyllic- and argillic-altered rocks in the Zagros magmatic arc, Iran, using Advanced Spaceborne Thermal Emission and Refl ection Radiometer (ASTER) data and logical operator algorithms: Geosphere, 2:161-186, 2 plates.

Meyer, C., and J.J. Hemley, 1967. Wall rock alterations. In Barnes, H.L. (Ed.), Geochemistry of Hydrothermal Ore Deposits, New York, Holt. Rinehart and Winston, 166-255.

Nesbitt, H.W. and G.M. Young, 1984. Prediction of Some Weathering Trends of Plutonic and Volcanic Rocks Based on Thermodynamic and Kinetic Considerations. Geochimica et Cosmochimica Acta, 48: 1523-1534.

Ninomiya, Y., 2003. A stabilized vegetation index and several mineralogical indices defined for ASTER VNIR and SWIR data. Proc. IEEE International Geoscience and Remote Sensing Symposium (IGARSS'03), Toulouse, France, 3, 1552-1554.

Ninomiya, Y., B. Fu, and T.J. Cudahy, 2005. Detecting lithology with Advanced Spaceborne Thermal Emission and Reflection Radiometer (ASTER) multispectral thermal infared "radiance-atsensor" data. Remote Sens Environ, 99: 127- 139. Corrigendum: Remote Sens Environ, 101, 567.

Novak, I.D. and N. Soulakellis, 2000. Identifying geomorphic features using Landsat-5/TM Data Processing Techniques on Lesvos, Greece, Geomorphology, 34(7): 101-109.

Oliver, J., 1986. Fluids expelled tectonically from orogenic belts: Their role in hydrocarbon migration and other geologic phenomena. Geology, 14(2): 99-102. 
Pour, B.A. and M. Hashim, 2011a. Identification of hydrothermal alteration minerals for exploring of porphyry copper deposit using ASTER data, SE Iran. J. Asian Earth Sci., 42:1309-1323.

Pour, B.A. and M. Hashim, 2012 b. Identifying areas of high economic-potential copper mineralization using ASTER data in Urumieh-Dokhtar Volcanic Belt, Iran. Adv Space Res., 49:753-769.

Rajendran, S., S. Al-Khirbasha, B. Pracejusa, S. Nasira, A.H. Al-Abria, T.M. Kusky, and A. Ghulam, 2012. ASTER detection of chromite bearing mineralized zones in Semail Ophiolite Massifs of the northern Oman Mountains: Exploration strategy. Ore Geol Rev., 44:121-135.

Rajendran, S., A. Thirunavukkarasu, G. Balamurugan, and K. Shankar, 2011. Discrimination of iron ore deposits of granulite terrain of Southern Peninsular India using ASTER data. J. Asian Earth Sci., 41: 99-106.

Ramadan, T.M., and M.F. Abdel Fattah, 2010. Characterization of gold mineralization in Garin Hawal area, Kebbi State, NW Nigeria, using remote sensing. Egypt J Remote Sens Space Sci., 13: 153163.

Rencz, A.N., 1999. Remote Sensing For the Earth Sciences. Wiley, USA

Ridley, J., 2013. Ore Deposit Geology. Cambridge university press. Colorado State University, 1041105.

Rose, A.N., 1970. Zonal relations of wall rock alteration and sulfide distribution of porphyry copper deposits. Econ. Geol., 65: 205-20.

Rowan, L.C., and J.C. Mars, 2003. Lithologic mapping in the Mountain Pass, California area using Advanced Spaceborne Thermal Emission and Refl ection Radiometer (ASTER) data: Remote Sensing of Environment, 84:350-366, doi: 10.1016/S0034-4257 (02)00127-X.

Ruiz-Armenta, J.R., and R.M. Prol-Ledesma, 1998. Techniques for enhancing the spectral response of hydrothermal alteration minerals in Thematic Mapper images of Central Mexico. International Journal of Remote Sensing, 19: 1981-2000.

Sabet, A.H., V.B. Tsogove, V.V. Bessonenko, V.A. Dyrenko, B.P. Butnko, and A.A. Zalata, 1973. Geological map of Bur Umm Qubur sheet Eastern Desert. Internal Report, Geological Survey of Egypt, 89.

Sabins, F.F., 1997. Remote Sensing principles and interpretation. W. H. Freeman Company, New York, 366-371.

Salem, S.M., M. El Sharkawi, Z. El-Alfy, N.M. Soliman, and S.E. Ahmed, 2016. Exploration of gold occurrences in alteration zones at Dungash district, Southeastern Desert of Egypt using ASTER data and geochemical analyses. Journal of African Earth Sciences, 117:389-400.

Salem, S.M., and N.M. Soliman, 2015. Exploration of gold at the east end of Wadi Allaqi, South Eastern Desert, Egypt, using remote sensing techniques. Arabian Journal of Geosciences. 8(11) : 92719282.

Stern, R.J., 1994. Arc assembly and continental collision in the Neoproterozoic East African Orogen: implications for the consolidation of Gondwanaland. Annual Reviews of Earth and Planetary Sciences 22, 315-319.

Suzen, M.L., and V. Toprak, 1998. Filtering of satellite images in geological lineament analyses: an application to a fault zone in Central Turkey. International Journal of Remote Sensing, 19:11011114.

Tangestani, M.H., and F. Moore, 2002. Porphyry copper alteration mapping at the Meiduk area, Iran. International Journal of Remote Sensing 23, 4815-4826.

Van Ruitenbeek, F.J.A., T.J. Cudahy, F.D. Van der Meer, and M. Hale, 2012. Characterization of the hydrothermal systems associated with Archean VMS - mineralization at Panorama, Western Australia, using hyperspectral, geochemical and geothermometric data. Ore geology reviews, 45: $33-46$.

Zhang, X., and M. Pazner, 2007. Comparison of Lithologic Mapping with ASTER, Hyperion and ETM Data in the southeastern Chocolate Mountains, USA. Photogrammetric Engineering and Remote Sensing, 73(5): 555-561.

Zoheir, B., A. Emam, M. Abd El-Wahed, and N. Soliman, 2019. Gold endowment in the evolution of the Allaqi-Heiani suture, Egypt: A synthesis of geological, structural, and space-borne imagery data. Ore Geology Reviews 110, 22. , 102938. https://doi.org/10.1016/j.oregeorev.2019.102938. 
Zoheir, B., and A. Emam, 2014. Field and ASTER imagery data for the setting of gold mineralization in Western Allaqi-Heiani belt, Egypt: A case study from the Haimur deposit. Journal of African Earth Sciences, 99 (1): 150-164 